OECD Education Policy Perspectives No. 16

\title{
EDUCATION POLICY OUTLOOK IN \\ GERMANY
}

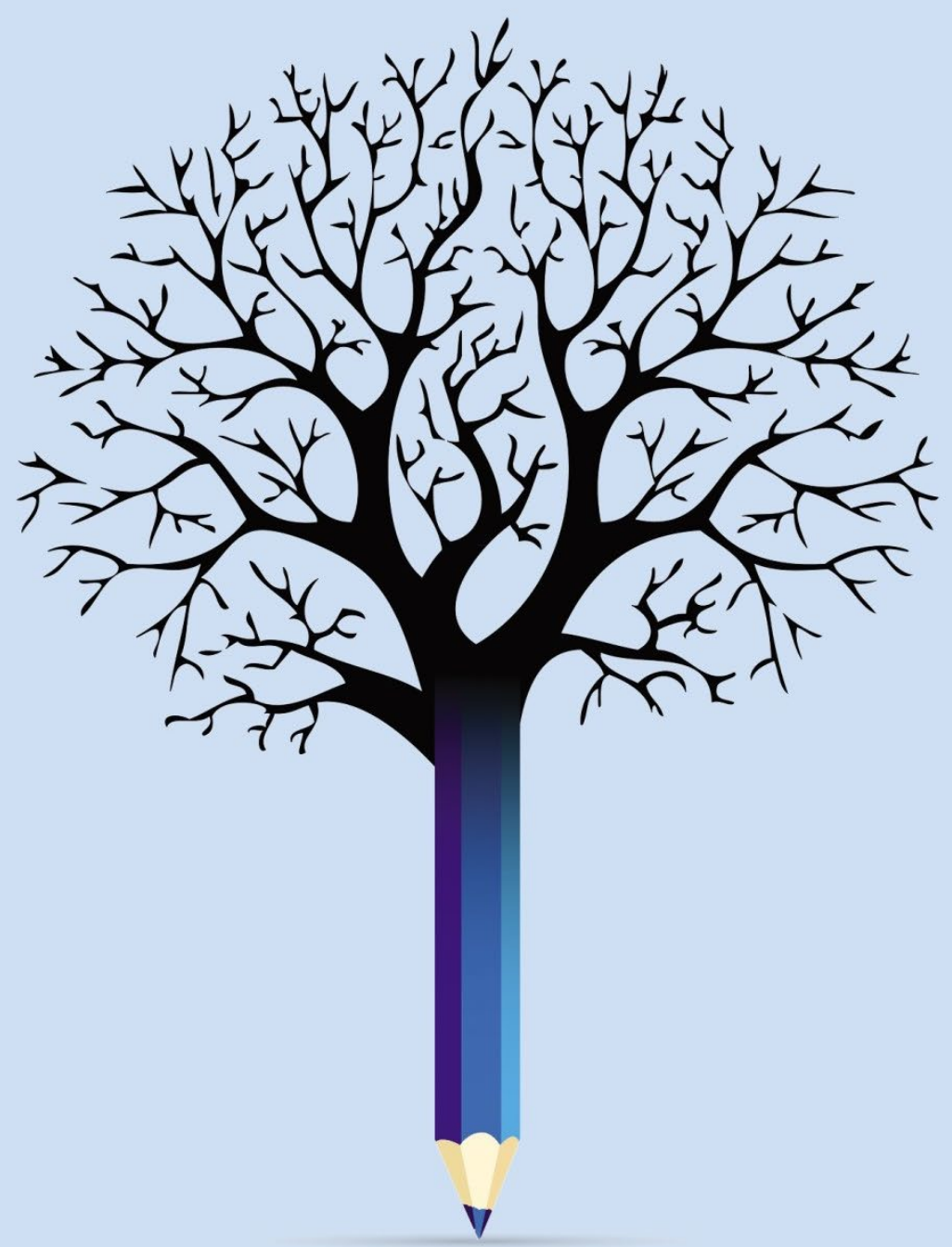




\section{EDUCATION POLICY OUTLOOK}

This policy profile on education in Germany is part of the Education Policy Outlook series, which presents comparative analysis of education policies and reforms across OECD countries. Building on the OECD's substantial comparative and sectoral policy knowledge base, the series offers a comparative outlook on education policy. This country policy profile is an update of the first policy profile of Germany (2014) and provides: analysis of the educational context, strengths, challenges and policies; analysis of international trends; and insight into policies and reforms on selected topics. It is an opportunity to take stock of progress and where the education system stands today from the perspective of the OECD through synthetic, evidencebased and comparable analysis.

In addition to country-specific profiles, the series also includes a recurring publication. The first volume, Education Policy Outlook 2015: Making Reforms Happen, was released in 2015. The second volume, Education Policy Outlook 2018: Putting Student Learning at the Centre was released in 2018. Its complement, Education Policy Outlook 2019: Working Together to Help Students Achieve their Potential was released in autumn 2019. Designed for policy makers, analysts and practitioners who seek information and analysis of education policy taking into account the importance of national context, the country policy profiles offer constructive analysis of education policy in a comparative format. Each profile reviews the current context and situation of a country's education system and examines its challenges and policy responses, according to six policy levers that support improvement:

- Students: How to raise outcomes for all in terms of 1) equity and quality and 2) preparing students for the future;

- Institutions: How to raise quality through 3) school improvement and 4) evaluation and assessment;

- System: How the system is organised to deliver education policy in terms of 5) governance and 6) funding.

Some country policy profiles contain spotlight boxes on selected policy issues. They are meant to draw attention to specific policies that are promising or showing positive results and may be relevant for other countries.

Special thanks to the German Government and, in particular, the Federal Ministry of Education and Research, the Standing Conference of the Ministers of Education and Cultural Affairs of the Länder in the Federal Republic of Germany (KMK) and the Federal Ministry of Family Affairs, Senior Citizens, Women and Youth, for their active input during consultations and constructive feedback on this report. We also thank the European Commission for its valuable analytical and financial support for the update of this country policy profile.

Authors: This country policy profile was prepared by Marie Ullmann, Diana Toledo Figueroa and Christa Rawkins in the Policy Advice and Implementation Division, led by Paulo Santiago. Editorial support was provided by Stephen Flynn and Rachel Linden. This profile builds on the knowledge and expertise of many project teams across the OECD's Directorate for Education and Skills, to whom we are grateful. Klaus Körner contributed on behalf of the European Commission Directorate-General for Education and Culture.

Sources: Subject to country participation, this country policy profile draws on OECD indicators from the Programme for International Student Assessment (PISA), the Survey of Adult Skills (PIAAC), the Teaching and Learning International Survey (TALIS) and the annual publication Education at a Glance, and refers to country and thematic studies such as OECD work on early childhood education and care, teachers, school leadership, evaluation and assessment for improving school outcomes, equity and quality in education, governing complex education systems, school resources, vocational education and training, and tertiary education. This profile also draws on information in the OECD Education Policy Outlook National Survey for Comparative Policy Analysis completed in 2016 by the German Government, as well as information provided by the Federal Ministry of Education and Research and the Federal Ministry of Family Affairs, Senior Citizens, Women and Youth and the KMK during 2018 and 2019 as part of the Education Policy Outlook's activities with countries.

Most of the figures quoted in the different sections refer to Annex $B$, which presents a table of the main indicators for the sources used throughout the country policy profile. Hyperlinks to the reference publications are included throughout the text for ease of reading, and also in the References and further reading section, which lists both OECD and non-OECD sources.

More information is available from the OECD Directorate for Education and Skills (www.oecd.org/edu) and its web pages on the Education Policy Outlook (www.oecd.org/edu/policyoutlook.htm).

In the context of the coronavirus (COVID-19) pandemic, some information is provided about initial responses. 


\section{No. 16 - EDUCATION POLICY OUTLOOK IN GERMANY}

\section{TABLE OF CONTENTS}

Highlights...

Equity and quality

Above-average performance, but equity challenges persist for disadvantaged students. . .8

Preparing students for the future

Growing levels of tertiary attainment, with room to improve transitions for VET students

ECEC and school improvement

Increased teacher shortages to be addressed in the coming years

Evaluation and assessment

System-level evaluation is being strengthened

Governance

A well-established structure of engagement with sub-national actors 17

Funding

High spending, with growing pressure as student numbers rise across the system 19

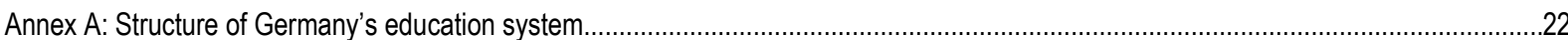

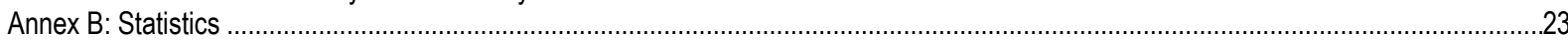

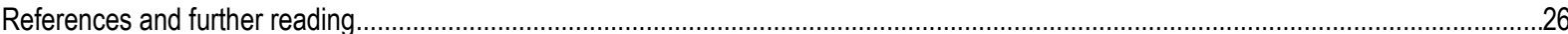

Notes 32

Figures

Figure 1. Trends and comparative performance of 15 -year-olds in reading, PISA

4

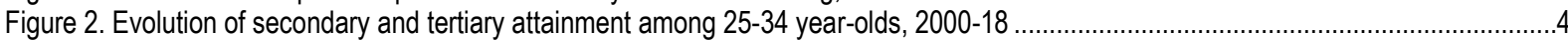

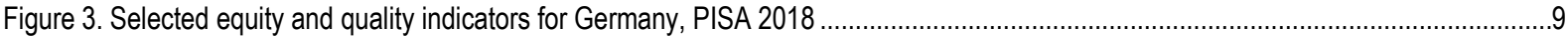

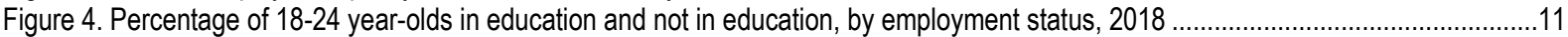

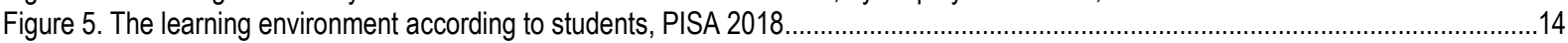

Figure 6. Percentage of students in schools where the principal reported assessments of students, PISA 2015 ....................................16

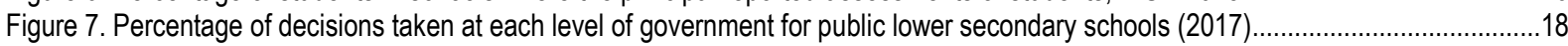

Figure 8. Annual expenditure per student (2016) and recent trends, by level of education ..................................................................20

Spotlights

Spotlight 1. Key policies, key challenges and previous OECD recommendations for Germany ...............................................................

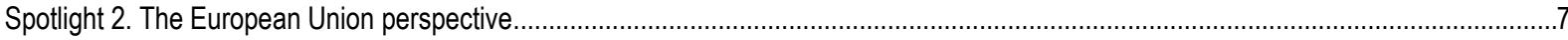

Spotlight 3. Facilitating the integration of migrants and refugees through VET initiatives ......................................................................12

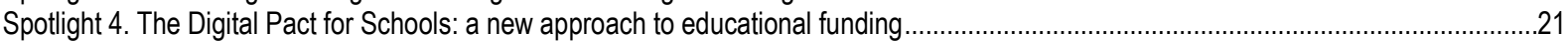




\section{3 | No. 16 - EDUCATION POLICY OUTLOOK IN GERMANY}

\section{HIGHLIGHTS}

Note: Most of the content in this profile was written before the COVID-19 outbreak. As such, this document offers insight into pre-existing conditions that may influence the system's responsiveness in the context of the crisis and help inform longer-term efforts to strengthen resilience.

\section{Germany's educational context}

Students: In PISA 2018 ${ }^{1}$, student performance in Germany was above average in reading, mathematics and science. Adults' skill levels are also strong: in the Survey of Adult Skills (PIAAC) 2012, numeracy skills were above average and literacy skills were similar to average. In addition, participation in early childhood education and care (ECEC) has grown considerably and is now above average for all ages, and near universal among 3-5 year-olds. With an extended period of compulsory education (ages 6-18), a larger share of Germans hold at least an upper secondary qualification than on average across the OECD. Among them, the share with a vocational qualification is also well above average. Tertiary attainment has also grown since 2008 , although more slowly than elsewhere in the OECD. Adults in Germany enjoy strong labour market outcomes with above-average wage and employability premiums for higher educational attainment.

Institutions: Working conditions for teachers in German schools and ECEC settings include above-average teaching hours with around average class sizes, and more competitive salaries compared to their peers in other countries, particularly at the start of a career. Students in Germany appear to perceive the school environment positively, with a higher-than-average index of sense of belonging and a lower-than-average rate of truancy. Relationships between students and teachers, however, are perceived by both parties to be less positive than on average across the OECD. Germany has made considerable efforts to strengthen system evaluation across the school and ECEC sectors, introducing national standards, assessments and evaluation institutions to support national-level monitoring. There are also ongoing efforts to increase the comparability of student assessment data within and between the Länder.

System: Within Germany's federal education system, the largest share of responsibility for decision-making is located at Länder level. Indeed, the Länder have more responsibility than state administrations in other federal systems, where schools and local administrations tend to have greater autonomy. Across all education sectors in Germany, engagement of sub-national actors plays a strong role; this is a key feature of the vocational system-for example, where employers contribute to aspects of governance and funding- and is a developing feature of tertiary education, where institutional governing boards with external representatives are increasingly being established. The latter development forms part of ongoing initiatives to strengthen institutional autonomy in the higher education sector, alongside more recent efforts to harmonise quality assurance processes across the Länder. In terms of funding, per-student spending in Germany is consistently above the OECD average for all levels of education, with particularly high levels in ECEC, vocational upper secondary and tertiary education, reflecting policy priorities.

\section{Key policy issues}

Germany experiences some important inequities in educational outcomes. In PISA 2018, socio-economic status had a larger impact on reading performance than on average across the OECD, and disadvantaged students are much less likely to gain a tertiary qualification. Despite considerable efforts to integrate new migrants, reading performance among foreign-born students in Germany declined between 2009 and 2018; they are also more likely to leave school prematurely. While progress was made in addressing such inequities following earlier PISA cycles, this appears to be slowing, if not reversing. Teacher shortages are felt across the education system, but more so in disadvantaged schools. An ageing teacher cohort, changes in the student population and declining attractiveness of the profession exacerbate such shortages. There is also an opportunity to better define and develop the school leader role, empowering principals to support teachers and drive school improvement. More consistent, improvement-focused approaches to school evaluation and teacher appraisal could also be developed. At system level, despite efforts to improve consistency across the Länder, disparities in capacity and funding persist. As student numbers grow, there is mounting pressure to ensure sufficient and efficient funding.

\section{Recent policy responses}

Germany has developed measures to integrate migrants through vocational education and training, including the Recognition Act (2012), the Vocational Language Training programme (2016) and the network of Co-ordination Offices for Vocational Training and Migration (enhanced from 2013). With the Digital Pact for Schools (2019), Germany aims to improve the digital infrastructure of schools, develop pedagogical content to equip children with ICT skills, and improve teachers' competencies. The Childcare Funding Act (2008) has been critical in providing financial support to the Länder to expand ECEC provision. With the Good Daycare Facilities Act (Gute-KiTa-Gesetz, 2019), the focus is shifting towards improving equity and quality. 


\section{4 | No. 16 - EDUCATION POLICY OUTLOOK IN GERMANY}

\section{KEY TRENDS IN PERFORMANCE AND ATTAINMENT}

In PISA 2018, students in Germany performed above the OECD average, at 498 score points compared to 487. Germany's reading performance has improved on average by 3.3 score points across PISA cycles since 2000 , although, more recently, such gains appear to be slowing, if not reversing. In the Survey of Adults Skills (PIAAC), at 270 points, Germany's mean performance in literacy was similar to the OECD average (268 points). The difference between younger and older adults was the largest among participating countries: 25-34 year-olds outperformed 55-65 year-olds by 27 score points in Germany, compared to an average gap of 16.

Figure 1. Trends and comparative performance of 15-year-olds in reading, PISA
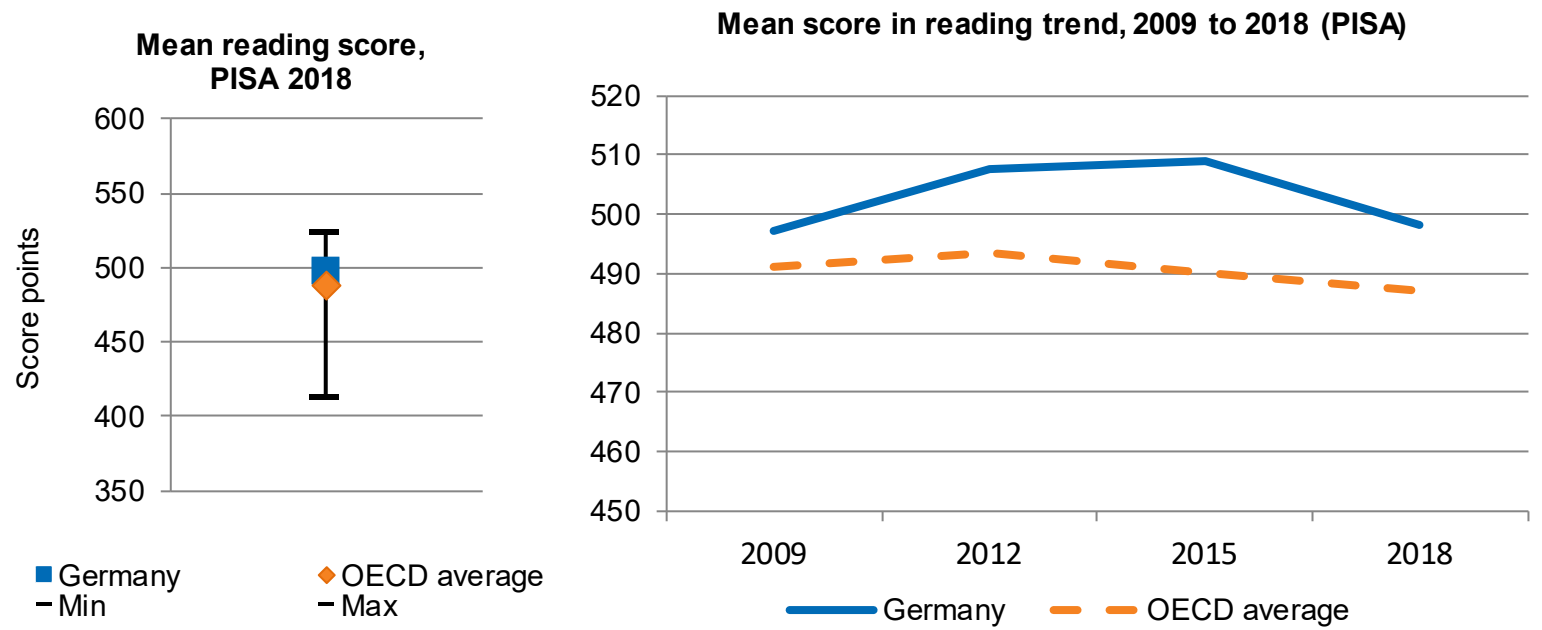

Note: "Min"/"Max" refer to OECD countries with the lowest/highest values.

Source: OECD (2019), PISA 2018 Results (Volume I): What Students Know and Can Do, PISA, OECD Publishing, Paris, https://doi.org/10.1787/5f07c754-en.

In $2018,87 \%$ of $25-34$ year-olds in Germany had attained at least upper secondary education, which was slightly above the OECD average of $85 \%$. Nevertheless, tertiary attainment among the same age cohort was well below the OECD average, at $32 \%$, compared to $44 \%$ during the same year. Furthermore, the increase in levels of tertiary attainment in Germany since 2008 has been slightly smaller than the average increase across OECD countries ${ }^{2}$. Among the tertiary-educated in Germany, there is a much more even gender distribution than on average across the OECD: the share of female graduates among 25-34 year-olds is only 3 percentage points higher than the share of male graduates, compared to an OECD average percentage-point difference of 13 .

Figure 2. Evolution of secondary and tertiary attainment among 25-34 year-olds, 2000-18
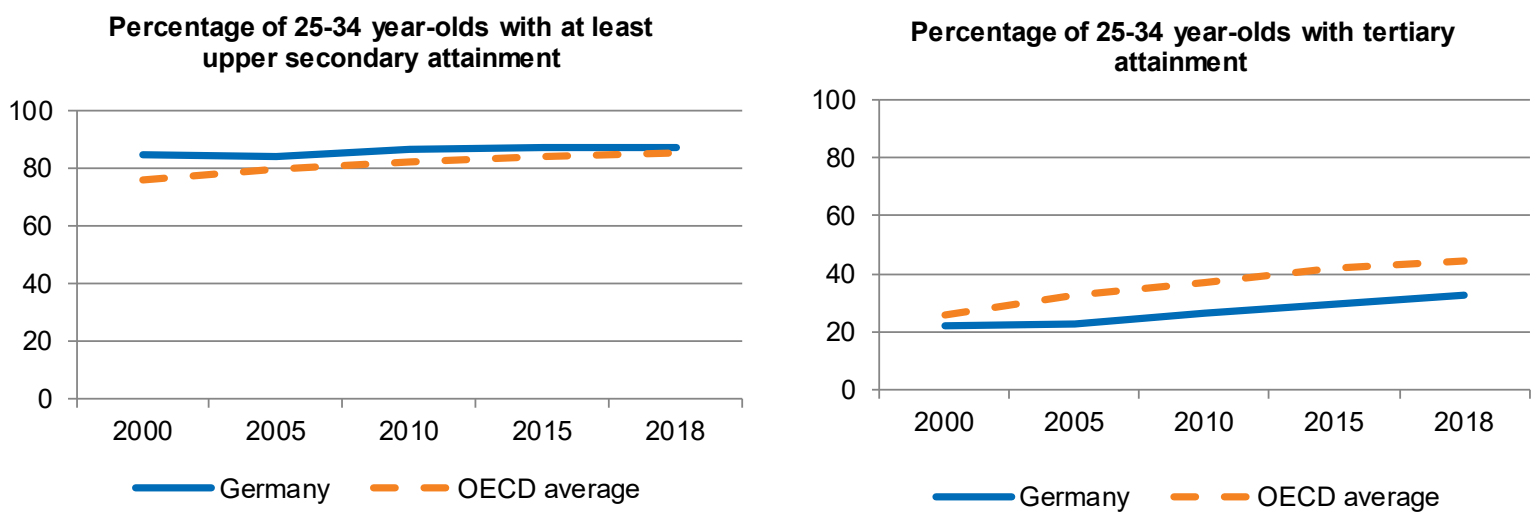

Source: OECD (2019), Education at a Glance 2019: OECD Indicators, OECD Publishing, Paris, https://doi.org/10.1787/f8d7880den. 


\section{Spotlight 1. Key policies, key challenges and previous OECD recommendations for Germany}

Main education policies and practices included in this country policy profile

\section{Key challenges and recommendations identified in previous OECD work}

\section{STUDENTS}

- Measures and reforms by the Länder to move away from early tracking

- Support for accessing ECEC: Stepping into childcare (KitaEinstieg, 2017)

- Language Daycare Centres (Sprach-Kitas, 2016)

- Good Daycare Facilities Act (Gute-KiTa-Gesetz, 2019-22)

- Support Strategy for High-Achieving Students (2015); federal government and Länder-approved initiative (Leistung Macht Schule, 2018-27); Support Strategy for Low Achieving Students (Förderstrategie für leistungsschwächere Schülerinnen und Schüler, 2010)

- Higher Education Pact 2020 (2006/07-20)

- Quality Pact for Teaching in Higher Education (2010/112020)

- The Future Contract for Strengthening Studying and Teaching in Higher Education (2019)

- Vocational Training Pact (2018)

- $\quad$ Shaping the Future - Innovation Clusters for vocational education and training (VET) Excellence competition (InnoVET, 2019)

- Vocational Schools 4.0 - (2017)

- Qualifications Opportunities Act (2018)

- National Skills Strategy (in adult learning) (Nationale Weiterbildungsstrategie, 2019)

- Recognition Act (2012)

- MySkills (2017)

- Vocational Language Training Programme (2016)

- Change of responsibility for the Co-ordination Office for Vocational Training and Migration (2013)

- Integration as an Opportunity (Integration als Chance, 2007)
Key challenges identified: The OECD has previously identified a need to improve ECEC in Germany to ensure both equity and quality [2016a]. Addressing equity more generally throughout the education system was also highlighted, particularly by further reducing stratification [2016a; 2018]. For vocational education and training (VET), the OECD previously noted a lack of transparency in programme content and expectations, varying course quality, and obstacles to student transitions from post-secondary VET to tertiary. For Fachschulen specifically, the OECD identified a need to make full use of workplace training [2013]. More recently, the OECD emphasised that Germany could improve upskilling opportunities in the VET system [2018]. Finally, the OECD also identified the need to strengthen continuous learning and to have a sufficient supply of high-skilled labour that can adopt to changing economic conditions $[2010,2016$ a]

Summary of previous OECD recommendations: OECD recommendations to improve ECEC have included expanding and increasing all-day provision and ensuring equal access for the most vulnerable [2016a]. To address equity concerns across the system, the OECD suggested delaying tracking, reducing the number of tracks available, improving inclusion for those with special educational needs, and expanding all-day primary provision. The OECD also proposed that refugee students be more quickly integrated into regular compulsory education [2016a; 2018]. Regarding VET, the OECD has suggested facilitating credit transfers between vocational and general programmes, improving industry self-regulation to foster quality and communicating the VET offer more effectively. For Fachschulen, the OECD recommended ensuring that workplace training is a mandatory part of the curriculum [2013]. OECD recommendations for lifelong learning include improving transparency in the adult education market and strengthening support for unskilled adults [2016ª, 2018].

\section{INSTITUTIONS}

- Joint initiative of the federal government and Länder to support disadvantaged schools (Schule macht Stark, 20212030)

- National programme to enhance the quality of teacher training (Qualitätsoffensive Lehrerbildung, 2014-23)

- Qualification of pedagogical specialists for inclusive education (2016)

- $\quad$ Skilled Labour Initiative: attracting new talent, retaining professionals in ECEC (2019-22)
Key challenges identified*: The OECD previously highlighted a need to improve ICT skills in schools. Furthermore, opportunities to strengthen teacher quality in ECEC, VET and general schooling have been identified by the OECD $\left[2010 ; 2013,2016^{b} ; 2018\right]$. The OECD has previously identified several challenges related to evaluation and assessment, including the lack of a national monitoring system for ECEC, the absence of children's views in monitoring data, and a need to enhance efficiency in the school system through improving accountability and- in the adult learning system- better evaluation. The 


\section{No. 16 - EDUCATION POLICY OUTLOOK IN GERMANY}

- Programmes to help refugees with teaching qualifications enter teaching in Germany: Refugee teacher programme (2015/University of Potsdam)

- Standards for Teacher Training: Educational Sciences (2004, revised in 2019)

- Global Strategy of the KMK for education monitoring (2006, revised in 2015), including Educational standards for the general higher education entrance qualification (Abitur) in some subjects (2012)

- Good Daycare Facilities Act (Gute-KiTa-Gesetz, 2019-22) Länder level: Berlin (2010); Hamburg (2020)
- Development of external evaluation of ECEC settings at

OECD also noted considerable variation in examination regulation across VET programmes [2010; 2013; 2016a,b]

Summary of previous OECD recommendations: The OECD previously recommended that Germany expand the use of ICT equipment in schools, improving teachers' digital skills and strengthening the digital offer in schools [2018]. Regarding teacher quality, the $\mathrm{OECD}$ has proposed: improving staff qualifications and working conditions in ECEC; holding teachers accountable for students progress in schools; and allowing teachers and trainers to be employed more flexibly in Fachschulen [2010; 2013; 2016ㅁ. The OECD also recommended setting up a central monitoring framework including children's views, with regular qualitative evaluation of pedagogical quality in ECEC, and using evaluation to guide full-day primary provision [2016 ${ }^{\text {b }}$ 2018]. For VET, OECD recommendations have included introducing a framework regulation and clear standards for all examinations, as well as more structured and institutionalised use of evidence on labour market demand and Fachschulen outcomes [2013].

\section{SYSTEM}

- National implementation of the United Nations Educational, Scientific and Cultural Organisation (UNESCO)'s Global Action Programme on Education for Sustainable Development (2015-19)

- Local Learning (2009-14); transfer initiative for municipal education management (2014)

- German Accreditation Council (2017)

- Good Daycare Facilities Act (Gute-KiTa-Gesetz, 2019-22)

- Childcare Funding Act (2008); fourth investment programmes (2017-20)

- Good Daycare Facilities Act (Gute-KiTa-Gesetz, 2019-22)

- Several Länder have fully or partially abolished the parental contribution fees for ECEC (since 2011)

- Excellence Strategy (2019)

- Berlin Bonus programme (2014)

- Digital Pact Schools - administrative agreement (2019); amendments to Art. 104c of the German Basic Law in order to allow co-funding between the federal government and the Länder in the field of digitalisation

- Education in the Digital World strategy (2016)
Key challenges identified*: The OECD has identified the need to improve equity and efficiency in various areas of the education system with opportunities for more targeted resource allocation [2010; 2013; 2016; ; 2018]. The OECD highlighted additional challenges regarding complex immigration rules that make it difficult for firms to fill vacancies for skilled workers [2010]. The OECD emphasised that further reform of the VET system was needed in order to ensure it responds flexibly to labour market needs [2016a]. Funding-related challenges identified by the OECD include constitutional barriers to federal co-funding for fullday primary education and a need to increase government investment in ECEC and higher education to support their expansion [2016a; 2018]

Summary of previous OECD recommendations: Recommendations on efficiency have included making tertiary education more attractive and responsive to labour market requirements [2010]. For VET, the OECD recommended letting VET schools and chambers jointly prepare and carry out the final examination of dual programmes [2010] Targeted funding measures previously recommended by the OECD include more generous grant-only financial support for students from low-income households at higher education institutions, financial support to encourage migrant families to take advantage of the ECEC offer and more resources for disadvantaged schools [2010; 2016a]. Due to the benefits of full-day primary schooling, the OECD also recommended reviewing constitutional barriers to funding [2016a]. The OECD also proposed improving tertiary-level funding and governance through increasing budgetary autonomy for institutions and increasing their input flexibility. Finally, providing more support for good municipa investment projects and strengthening administrative capacity was also recommended [2016a].

Note: The information on key challenges and recommendations in this spotlight draws from a desk-based compilation from previous OECD publications (subject to country participation). The spotlight is intended for exploratory purposes to promote policy dialogue, and should not be considered an evaluation of the country's progress on these recommendations. Causality should not be inferred either: while some actions taken by a country could correspond to previous OECD recommendations, the OECD acknowledges the value of internal and other external dynamics to promote change in education systems.

Sources: 2010, 2016a ${ }^{a}$ 2018: The Economic Survey of Germany; 20162: Monitoring Quality in Early Childhood Education and Care: Country note Germany; 2013: Reviews of Skills Beyond Schools: Germany 


\section{Spotlight 2. The European Union perspective: \\ Germany's education and training system and the Europe 2020 Strategy}

In the European Union's growth and employment strategy, Europe 2020, education and training is recognised as a key policy area in contributing to Europe's economic growth and social inclusion. The European Union set a twofold target in education by 2020: reducing the rates of early school-leaving below $10 \%$, and reaching at least $40 \%$ of 30-34 year-olds completing tertiary or equivalent education. Countries set their own related national targets. The Europe 2020 goals are monitored through the European Union's yearly assessment of the main economic and growth issues.

The European Semester Country Report 2020 identified a number of key issues for Germany in education and training:

- Early school-leaving of $18-24$ year-olds, at $10.3 \%$ in 2019 , is similar to the European average $(10.2 \%$ ) as well as to the national target, which is less than $10 \%$. There are important regional differences: with $16.06 \%$ in Bremen or Hamburg, against $10.3 \%$ on average nationwide, and only $6.9 \%$ in Swabia (Schwaben). The rate remains unchanged compared to 2018 and evolved little between 2010 and 2019 .

- Germany is continuing to increase tertiary attainment among $30-34$ year-olds, which stood at $35.5 \%$ in 2019 , but remained below the EU average of $40.3 \%$ and the EU target of $40.0 \%$. The national target of $42 \%$ also includes ISCED 4 (unlike the EU target), and has thus been met (49.8\% in 2018). Attainment differs significantly (by 30 percentage points) between regions.

- Basic skill proficiency of young students remains broadly unchanged while socio-economic background continues to have a strong impact on education outcomes. The share of 15 -year-olds with disadvantaged socio-economic backgrounds who underperform in reading is 27.5 percentage points higher than for those with more advantaged socio-economic backgrounds above the EU average. There is a more pronounced performance gap (more than one PISA competence level) between academic and vocational lower secondary schools. Germany is among the countries with the widest gap in underachievement rates in reading between students born abroad and students without migrant backgrounds, and the gap has grown significantly since 2009.

- Inequalities in educational attainment persist, with socio-economic and migrant backgrounds still having a strong influence. Since 2010, foreign-born people continue to leave education more than three times more often than native-born people. Young people from a disadvantaged socio-economic background are three times less likely to be in higher education. Attainment rates in both higher and vocational education are lower for people from a migrant background than for native-born people. Despite serious efforts to integrate recently arrived people with a migrant background, particularly in vocational education and training, their likelihood to start training is about half of the native-born.

- Serious teacher shortages are putting a strain on the education system. According to the German Teachers' Association, in 2019/2020 around 15000 posts will remain vacant, while 40000 posts will be filled by people who were not trained originally as teachers. Teacher shortages threaten the comprehensive provision of quality education due to cancelled classes and a challenge is presented by relying on people who have no formal teacher training, with potential negative repercussions for the intended expansion of all-day schooling, as well as for integrating recently arrived migrants.

- The expansion of early childhood education and care (ECEC) places is progressing, but large supply gaps remain. Lack of attractiveness of jobs cause serious shortages of qualified personnel and municipalities invest rather in abolishing fees (widely preferred by parents) instead of in improving quality.

- Despite recently increased investment among others in digitalisation, higher education, and school infrastructure and quality, Germany spent $4.2 \%$ of gross domestic product (GDP) in 2018, the same as in 2015 , and the share of education in public expenditure amounted to $9.4 \%$. This is about half a percentage-point below the EU value. Important investment gaps remain, in particular in digitalisation and municipal school infrastructure.

In May 2020, the Council of the European Union proposed the following country-specific recommendation to Germany, with regard to education: "...Focus investment on the green and digital transition, in particular on [...] digital infrastructure and skills, [...], education and research and innovation". Subject to its endorsement, this recommendation will be formally adopted in July 2020. 


\section{EQUITY AND QUALITY: ABOVE-AVERAGE PERFORMANCE, BUT EQUITY CHALLENGES PERSIST FOR DISADVANTAGED STUDENTS}

Germany combines above-average performance in reading with lower-than-average PISA equity indicators. In PISA 2018, students in Germany also performed above OECD average in mathematics and science. In all three domains, Germany had a smaller share of low performers (below PISA Level 2) and a larger share of top performers (Level 5 or above) compared to the OECD average. Over the longer term, reading performance has improved and remains stable since 2009 (see Figure 1), while mathematics performance has remained stable since 2003, with significant decreases since 2012. Science performance decreased considerably since 2006, and more so in recent years. Gender differences in reading narrowed by 14 points since 2009 , due to both improved boys' results and a decline in girls' results. The share of boys performing at Level 5 or above increased by 5 percentage points over the period while the share of girls performing below Level 2 increased by 3.7 (compared to OECD average change of 2.1 and 4.4, respectively). Performance differences by gender also decreased in mathematics; this was due to a decline in boys' performance. In science, girls outperformed boys for the first time in PISA 2018, also due to a significant decrease in boys' performance since 2015. In PISA 2018, 22.2\% of students in Germany were from immigrant backgrounds ${ }^{3}$, representing an increase of 4.5 percentage points since 2009. After accounting for socio-economic background, the performance difference between all immigrant and non-immigrant students in Germany was 17 points, compared to 24 points on average. Nevertheless, while the gap decreased from 17 to 8 score points for second-generation immigrants between 2009 and 2018, it increased from 31 to 70 for first-generation immigrants.

Early childhood education and care (ECEC) policies can increase the equity of education systems. In Germany, children are legally entitled to a place in ECEC from 1-6 years old although conditions of access, including cost and hours, vary between the Länder. At age 3, children in Germany begin kindergarten (Kindergärten), which usually lasts for three years. Some Länder have established one-year pre-school programmes, under various names, for children who have reached compulsory schooling age, but whose level of development does not yet allow them to cope with the challenges of primary school. Participation in ECEC is high: at $95 \%$, the share of 3-5 year-olds in Germany enrolled exceeded the OECD average of $87 \%$ in 2017 . Among children under 3 , the enrolment rate was $37 \%$, compared to $36 \%$ on average, having increased by 20 percentage points since 2005 . The OECD (2018) reported that children from immigrant backgrounds and/or socio-economically disadvantaged families are less likely to attend ECEC in Germany, or more likely to begin at a later age. Additionally, research into the quality of day care (2018) indicates that considerable variation in access between the Länder persists.

According to OECD evidence, some system-level practices in Germany may favour equity. Compulsory schooling begins at age 6 and ends at 18, two years longer than is most common in the OECD, yet other practices may hinder equity if not managed carefully. Germany tracks students into educational pathways, generally at age 10 (grade 5$)^{4}$, the earliest in the OECD. Except for Bavaria, the Länder have moved away from the three-pathway model of academically oriented Gymnasium, and vocationally-oriented Realschule and Hauptschule. Besides Gymnasium, the main school types now available are integrated (all three tracks combined), semi-integrated (Hauptschule and Realschule combined) or cooperative (all or two tracks combined with tracking from grade 6). In PISA 2018 though, $54 \%$ of the variance in Germany's reading scores was explained by between-school variation (the OECD average was $29 \%$ ). Academic differences may intersect with socio-economic differences: the isolation index for disadvantaged students from high-performing students was 0.72 , compared to 0.67 on average. Also, tracking may persist in a new form: in PISA 2015, both between- and in-class ability grouping at school increased substantially from 2006, although it remained close to average levels. Grade repetition is also more common in Germany: in PISA 2015, 18\% of 15-yearolds reported having repeated a grade, compared to $11 \%$ on average.

Despite improvements, students' socio-economic background in Germany continues to have one of the largest impacts on performance in the OECD. In PISA 2018, socio-economic status explained $17.2 \%$ of the variance in reading scores in Germany compared to $12 \%$ on average. The mean performance gap between advantaged and disadvantaged students in 2018 was 113 score points in Germany, the equivalent of 3.5 years of schooling (the OECD average performance gap was 89 score points). Germany undertook several measures to address these inequities, including the introduction of national education standards and all-day schooling. Subsequently, the score difference associated with a one-unit increase in the PISA index of economic, social and cultural status (ESCS) narrowed by 8 points to 44 points overall in Germany between 2000 and 2009. More recent trends suggest the gap is once again growing though.

\section{Key strengths and challenges in equity and quality}

\section{Key strengths}

- Germany performed above the OECD average in reading, mathematics and science in PISA 2018.

- ECEC enrolment among younger children has grown considerably, while remaining lower among immigrant and disadvantaged students.

\section{Key challenges}

- Germany's practice of early tracking may foster informal forms of segregation between schools.

- Socio-economic background has a substantial impact on students' educational performance. 


\section{9 | No. 16 - EDUCATION POLICY OUTLOOK IN GERMANY}

\section{Recent policies and practices}

Stepping into Childcare (Kita-Einstieg, 2017) supports innovative approaches that support immigrant or disadvantaged families' access childcare. With 150 locations nationwide, the programme reached around 32000 people by 2020 with over 3100 children transitioning to daycare. Initiatives include play groups and parent-child groups, information services for parents and qualification programmes for staff. The Language Daycare Centres programme (Sprach-KiTas, 2016), which is targeted at centres with an above-average share of children with language development needs, finances 7000 specialists to support staff with language and inclusive education working with families in around one-tenth of settings in Germany. An interim report (2019) found the programme contributed to increasing the skills of ECEC staff and the quality of interaction with children. Recommendations included increasing collaboration between staff and partnership models across settings to extend good practice.

A national education evaluation (2018) noted a continued need to focus on raising quality in ECEC and growing demand for highly skilled ECEC staff with clearer qualification and development processes. The Good Daycare Facilities Act (Gute-KiTa-Gesetz, 2019) addresses these issues and others by formally steering policy across ten areas, including pedagogy, staff qualifications and institutional management and networking, as well as lower parental fees. The federal government reached individual agreements with the Länder committing EUR 5.5 billion to the project up to 2022 (see "Funding").

In 2016, the federal government and the Länder agreed on a jointly-funded initiative to support high-achieving (and potentially highachieving) students in primary and lower secondary education (Leistung Macht Schule, 2018-27), with a focus on improving diagnosis and optimising learning through stronger teaching, a school culture that values achievement, and enrichment activities. In phase one (2018-22), an interdisciplinary research alliance of 16 universities supports 300 schools in developing school culture and targeted educational content. Through 22 subprojects, the alliance addresses support for targeted students during classes and transitions, and through collaboration among teachers and schools. The jointly developed concepts and tools are continually evaluated and optimised. Supported by the alliance, crossschool networks encourage reflection, dissemination and collaboration. Phase two (2023-27) will focus on sharing evaluated best practice. Between PISA 2009 and 2018, the share of top performers in reading increased, remained stable in science, and decreased in mathematics.

The Support Strategy for Low Achieving Students (Förderstrategie für leistungsschwächere Schülerinnen und Schüler, 2010) aims to increase the share of students reaching minimum proficiency by the end of secondary education. The Länder implemented a range of initiatives which focused, among others, on personalised support, facilitating transitions, collaboration with other actors, and quality assurance and research. An evaluation (2017) reported a considerable reduction in the share of students leaving secondary education without a qualification.

Figure 3. Selected equity and quality indicators for Germany, PISA 2018

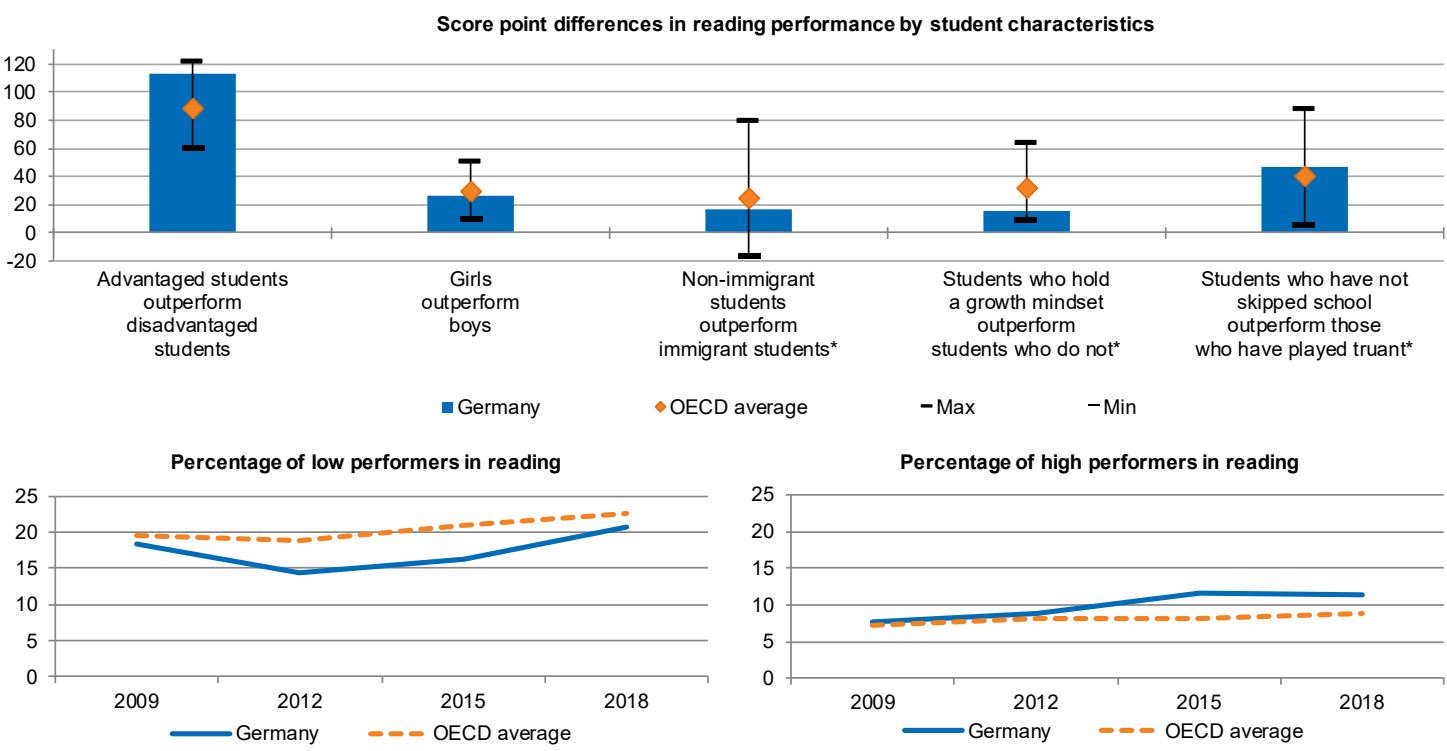

Note: "Min"/"Max" refer to OECD countries with the lowest/highest values; [*] Score point difference after accounting for students' socioeconomic status and language spoken at home.

Sources: OECD (2019), PISA 2018 Results (Volume l): What Students Know and Can Do, PISA, OECD Publishing, Paris, https://doi.org/10.1787/5f07c754-en; OECD (2019), PISA 2018 Results (Volume II): Where All Students Can Succeed, PISA, OECD Publishing, Paris, https://doi.org/10.1787/b5fd1b8f-en; OECD (2020), PISA 2018 Results (Volume III): What School Life Means for Students' Lives, PISA, OECD Publishing, Paris, https://doi.org/10.1787/acd78851-en. 


\section{PREPARING STUDENTS FOR THE FUTURE: GROWING LEVELS OF TERTIARY ATTAINMENT, WITH ROOM TO IMPROVE TRANSITIONS FOR VET STUDENTS}

The capacity of a country to effectively develop skills and labour market perspectives can play an important role in the educational decisions of the population. Higher educational attainment leads to high skill levels in Germany. In the OECD Survey of Adult Skills, Germany's literacy scores were similar to average (see Figure 1), but numeracy scores were above average at 272 score points compared to 263. In literacy and numeracy, mean performance differences among 1665 year-olds with a tertiary qualification and those with upper secondary only, were among the largest in the OECD, at 55 and 69 score points respectively. However, adults in Germany enjoy positive labour market conditions across attainment levels: the employment rate was above average for 25-64 year-olds, in 2018 (81\% compared to $77 \%$ ) and was especially high for tertiary-educated $25-34$ year-olds (88\% compared to $84 \%$ ). Among the same cohort, employment rates for upper secondary or post-secondary non-tertiary graduates grew by 6 percentage points from 2008 , reaching $84 \%$ in 2018 , compared to $78 \%$ on average. Moreover, the share of $18-24$ year-olds who were not employed, or in education or training (NEET), in 2018 was below average at $9.6 \%$ compared to $14.3 \%$. However, immigrants face larger educational challenges. According to the OECD/EU (2018), in 2016, early school-leaving rates reached $18.9 \%$ among foreign-born $15-24$ yearolds who arrived as children, compared to $8.9 \%$ for native-born with foreign-born parents and $5.5 \%$ for native-born with native-born parents ${ }^{5}$. In 2017 , foreign-born $15-29$ year-olds were over three times as likely to be NEETs as their nativeborn peers.

In Germany, upper secondary education is compulsory and typically lasts three years. Students may enter general upper secondary programmes (gymnasiale Oberstufe), offered by Gymnasien or Gesamtschulen leading to an upper secondary general school-leaving certificate (Abitur), which enables entry to any higher education programme. Alternatively, students can attend one of four vocational streams, which lead either to the Fachgebundene Hochschulreife qualification, entitling the holder to study particular subjects in a higher education institution (HEI), or the Fachhochschulreife qualification for entrance to universities of applied sciences. In 2018, about 10.5\% of the typical age group obtained the Fachhochschulreife. Students from the dual system (first cycle) or from specialised vocational schools must obtain an occupational qualification before continuing either to specialised vocational upper secondary schools (Berufsoberschulen), the dual system (second cycle), or health and social sector programmes. At $87 \%$, Germany's share of adults with at least an upper secondary qualification was above the OECD average of $83 \%$ in 2018 .

Vocational education and training (VET) can ease entry into the labour market, yet across the OECD, many VET programmes make insufficient use of workplace training. Germany's VET system is internationally renowned and dual programmes are available in over 300 trades. In 2016, Germany had one of the highest shares of 25-34 year-olds with vocational upper secondary or post-secondary non-tertiary attainment in the OECD, at $47 \%$, nearly double the average. Yet the rate at which VET graduates enter tertiary education is low, suggesting that although transition pathways exist, they are not commonly used. The OECD (2018) reported that although many vocational graduates initially earn more than academic graduates, their earnings increase little with experience. Furthermore, the EC (2019) reported that VET programmes are becoming less attractive among young Germans. Improving access to tertiary education for VET students may help counter this, as could strengthening general education elements within VET, especially given that rapid technological advancement and the risk of automation increasingly call for upskilling and reskilling. As reported by the OECD (2019), Germany has a high share of jobs at risk of automation or significant change, yet according to the EC (2018), participation in adult education remains low.

Higher education in Germany follows the Bologna model. HEls are largely divided into universities, specialised institutions of university standing, universities of applied sciences (UAS) and universities of art and music. Universities and specialised institutions of university standing, as well as some of the UAS, have the right to award a doctorate. The wage premium for tertiary graduates in Germany relative to upper secondary was among the highest in the OECD in 2017, at $69 \%$, compared to $57 \%$. In 2018 , however, levels of tertiary attainment remained below the OECD average, despite some growth (see Figure 2). Germany has undertaken various policy measures to increase tertiary attainment (see "Recent policies and practices"'), which is comparatively lower, at least in part due to early tracking and the strength of the vocational sector. Certain professions requiring a tertiary qualification in other countries can be accessed through the vocational track in Germany. In Germany, only $15 \%$ of 25-64 year-olds whose parents did not have an upper secondary qualification went on to graduate from a tertiary programme, compared to $20 \%$ across the OECD in 2015 . Furthermore, in PISA 2018, an advantaged student in Germany was more than four times as likely to report expecting to gain a tertiary qualification as a disadvantaged student.

\section{Key strengths and challenges in preparing students for the future}

\section{Key strengths}

- Higher educational attainment is related to higher skills, and employability is good on average for different levels of education attainment.

- A strong VET sector at upper secondary level.

\section{Key challenges}

- Employability and educational attainment are considerably lower for foreign-born persons.

- Levels of tertiary attainment are below average. 


\section{Recent policies and practices}

Germany's Higher Education Pact 2020 (HEP, 2007-20), a joint measure between the federal government and the Länder, aims to ensure higher education institutions (HEls) meet growing demand by establishing additional study places. An interim evaluation (2017) of the first two phases (2007-15) found that by 2015 , the number of students entering HEls was up by $40 \%$ from 2005 and the number of courses offered had increased dramatically. However, although staff numbers also grew, student-staff ratios decreased and efforts to improve teaching quality were less conclusive. Following this, the third phase (2016-20) aims to finance up to 760000 additional study places, increase the number of academic staff and improve professional development. The federal government has dedicated EUR 20.2 billion and the Länder EUR 18.3 billion.

Within the HEP, Germany also introduced the Quality Pact for Teaching in Higher Education (Qualitätspakt Lehre, 2010). Phase one (2011-16), provided funding to $186 \mathrm{HEls;}$; phase two reached 156. Projects target pedagogical development, working conditions, and competence-oriented learning. An initial evaluation (2016) praised the Pact for putting quality teaching at the centre of higher education discourse and for positive collaboration between HEls. Following both Pacts, in 2019, the federal government and the Länder signed the Future Contract for Strengthening Studying and Teaching in Higher Education (Zukunftsvertrag Studium und Lehre stärken) an openended commitment to contribute annually around EUR 2 billion each to strengthen higher education. A new body dedicated to innovation in higher education teaching is also being established, with an annual budget of EUR 150 million.

The Vocational Training Pact (VTP, 2018) constitutes a formal commitment from the federal government and the Länder to modernise VET by harnessing digital tools, upgrading equipment and increasing flexibility and permeability between tracks. An amendment (2019) to the Vocational Training Act introduced a minimum training allowance, and C-VET qualifications to give greater equivalency between general and vocational studies, and expanded part-time training. The Ministry of Education and Research (BMBF) also launched the Shaping the Future - Innovation Clusters for VET Excellence competition (InnoVET, 2019) inviting regional and industry-specific actors to collaborate on innovative modes of VET provision. In the initial six-month development phase, 30 projects were allocated EUR 100000 ; further funding will be assigned for the subsequent testing and implementation phase (up to four years). With the resolution Vocational Schools 4.0 - Further Development of the Innovative Strength and Integration Performance of Vocational Schools in Germany in the Coming Decade (2017), the Länder have defined an action framework to prepare vocational schools for future challenges. Strategic fields of action include strengthening innovation through enhancing collaboration both internationally and with employers, fostering successful integration into VET among all target groups, developing language training and individualised support, and improving the quality of education and training provision through sharing good practice on quality management and professionalising VET staff.

In response to changing labour demands, the federal government passed the Qualifications Opportunities Act (Qualifizierungschancengesetz, 2018) enabling all employees whose work is at risk to access training regardless of qualification, age and size of company. The inaugural National Skills Strategy in adult education (Nationale Weiterbildungsstrategie, NWS, 2019), in C-VET (continuing vocational education and training), adopted by the federal government, Länder, industry, trade unions and the Federal Employment Agency, aims to establish a new national culture of lifelong learning. All partners agreed to make training opportunities and funding more transparent and accessible. The first evaluation is scheduled for 2021.

\section{Figure 4. Percentage of 18-24 year-olds in education and not in education, by employment status, 2018}

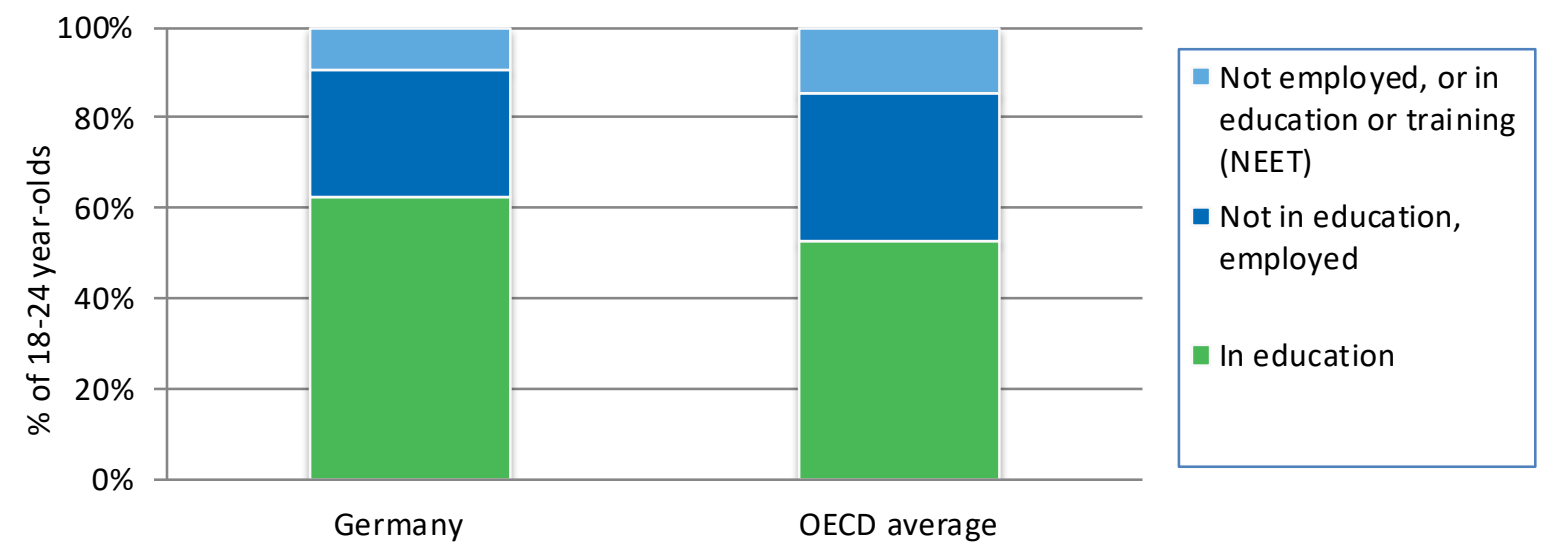

Source: OECD (2019), Education at a Glance 2019: OECD Indicators, OECD Publishing, Paris, https://doi.org/10.1787/f8d7880den. 


\section{Spotlight 3. Facilitating the integration of migrants and refugees through VET initiatives}

In recent years, Germany has experienced a considerable increase in the number of migrants entering the country. According to the OECD's International Migration Database, between 2007 and 2017, the total number of new arrivals to Germany grew from around 575000 to 1.4 million, with a peak of 2 million in 2015. In this context, the share of asylum seekers grew substantially and young adults and children were over-represented. Germany has thus faced the challenge of successfully integrating these new arrivals in education and training, not only to uphold humanitarian commitments, but also to facilitate social cohesion and improve future economic outcomes.

In response, and building on the former National Integration Plan (2007), the Integration as an Opportunity declaration (Integration als chance, 2007), which emphasised the importance of education for the successful integration of young immigrants, and the National Action Plan on Integration (2011), the federal government and the Länder have extended, strengthened or introduced numerous integration initiatives. Measures to promote participation in the VET system have been particularly important. These include:

- Qualification recognition: Although migrants may not have a formal VET background, the majority have previously been employed Therefore, recognising or validating skills and qualifications is essential to assess training needs or labour market readiness. Germany's Recognition Act (2012) legally entitled all migrants to such procedures, regardless of status. A report on the Recognition Act (2017) noted that in five years, the number of recognition processes more than doubled to almost 25000 , including a substantial increase for refugees. The Federal Employment Agency (BA) also developed the MySkills (Berufliche Kompetenzen erkennen, 2017) computer-assisted tests. As of 2019, the tests exist for eight professions in six languages and are offered by all Public Employment Services, which also provide feedback and follow-up advice. The BA is developing tests for a further 22 professions. The EC (2018) praised the initiative, particularly the use of visual-based learning and simulation, alignment with professional standards, and affordability.

- Preparatory courses: A key challenge for new arrivals is the acquisition of language and basic competences. The OECD (2017) reported that vocationally-oriented language courses can be powerful integration mechanisms. Such courses exist in Germany since 2008 (co-financed by the EU); in 2015, the government put this type of training at the heart of integration policy. The Vocational Language Training programme (berufsbezogene Sprachförderung, 2016) has a budget of EUR 175 million to provide relevant training via public and private bodies. Additionally, all Länder introduced preparatory classes for vocational schools, generally a one- or twoyear course preparing migrants to secure an apprenticeship. According to the OECD (2019), the share of immigrant students attending such programmes grew from 18000 in 2014/15 to 81000 in 2016/17. Although other initiatives also combine language learning and VET, the OECD recommended scaling up the provision of preparatory courses, highlighting survey data which indicate coverage deficiencies.

- Facilitating dual VET: In 2013, BMBF took over responsibility for the Co-ordination Office for Vocational Training and Migration (KAUSA, 1999) establishing more than 30 agencies across the country. These regional advisory and co-ordination centres support students and employers with a migrant background to engage in dual VET. In 2015, the target group expanded to include refugees. According to national data, since 2013, BMBF has invested almost EUR 30 million in the project and reached around 20000 young people and 5000 employers. However, the OECD (2019) reported that, given the finite mandate of the project, more sustainable support mechanisms are needed, particularly as migrants are less likely to secure an apprenticeship than their non-migrant peers, even when accounting for context. Länder-level innovations also exist, enabling migrants to receive additional language training during their vocational programme in order to achieve learning objectives. In Bavaria, for example, a pilot project is experimenting with a $1+3$ dual VET model where apprenticeships are combined with vocational language learning. Apprentices can thus improve their language skills while earning a salary and gaining work experience

Efforts to leverage Germany's strong VET system to support the integration of migrants are not new, but have become more urgent with the considerable increase in arrivals from 2015. Many more efforts exist than those detailed above, leaving a patchwork of programmes, initiatives and projects under the authority of a variety of public, and, indeed, private bodies. This implementation approach has benefits: the OECD (2019) has reported that the impressive range of measures creates a unique context and valuable lessons for other countries, particularly regarding the breadth of stakeholder engagement. The approach creates an environment of experimentation for mutual learning and has also enabled Germany to respond effectively to the spike in arrivals.

However, this approach also risks inconsistencies in quality and challenges the federal government's ability to maintain a strategic overview. Furthermore, the OECD has emphasised that data collection for monitoring and evaluation in this area has long required improvement in Germany and may not be strong enough to capitalise on this networked approach by identifying and disseminating best practice. The national VET report (2018) highlighted that people with a migrant background continue to face greater obstacles when accessing VET and are only half as likely to enter a VET programme as non-immigrants. 


\section{ECEC AND SCHOOL IMPROVEMENT: INCREASED TEACHER SHORTAGES TO BE ADDRESSED IN THE COMING YEARS}

At school level, developing positive learning environments for students that enable school leaders and teachers to succeed is essential in raising achievement. In PISA 2018, 15-year-olds reported a greater sense of engagement and connectedness with the school community than on average across the OECD with an index of sense of belonging ${ }^{6}$ of 0.28 compared to an average of 0.00 . Furthermore, in 2018 , only $13 \%$ of 15 -year-olds in Germany reported skipping at least one day of school in the two weeks prior to the PISA test, compared to $21 \%$ on average. However, students' perceptions of their relationships with teachers were less positive: the index of teacher support in Germany was among the lowest in the OECD, at -0.24 , compared to an OECD average of 0.01 .

Attracting, retaining and developing good-quality school leaders is critical to improving the quality of learning environments and promoting effective school leadership. In Germany, prospective school leaders require a teaching qualification and experience, and benefit from additional qualifications. Most $L a ̈ n d e r$ provide preparatory training. The role differs across Länder, but responsibilities generally include staff and budget management, external relations, teacher appraisal and teaching. School leaders' authority in Germany is relatively limited, though, and teachers' pedagogical freedom is legally enshrined in most Länder. As such, principals' time is more focused on administrative matters than on instructional leadership. However, many Länder have been employing more administrative staff in order to reduce the administrative burden. In PISA 2015, Germany's index of instructional leadership was only slightly below the OECD average, at -0.02, compared to 0.00. At ECEC level, according to self-reports in TALIS Starting Strong 2018, although three-quarters of ECEC leaders in Germany received early-childhood-focused training, only one-third had attended pedagogical leadership training, which was by far the smallest share among participating countries. Across the system, there are no national leadership standards for educators and professional development is not a federal requirement, although the Länder do provide initial and continuous training opportunities. The EC (2019) reported that the role of school leader in Germany could be more attractive with evidence of shortages at primary level; this correlates with shortages among primary school teachers. In recent years, some Länder have increased salaries of school leaders to make the profession more attractive.

A strong supply of highly qualified and engaged teachers is vital in every education system. Aspiring teachers must complete a specific tertiary course, of between 3.5 and 4.5 years. In many Länder, teacher education has become a consecutive structure of Bachelor and Master's degree. Once prospective teachers pass this course and the qualifying examination (Erste Staatsprüfung), they follow a teacher practicum (Vorbereitungsdienst), of between 18 and 24 months, leading to a further examination (Zweite Staatsprüfung). Although there is a large range of teacher careers across Länder, education level, or school type, six types of professional careers can be identified. Professional development is mandatory for all teachers and influences career progression. The recent Resolution for Teacher Training (2020), saw the Länder commit to common key points for teacher professional development. Germany's teaching cohort is ageing though: $42 \%$ were aged 50 or over in 2017, compared to an OECD average of $36 \%$. As they approach retirement, this may exacerbate teacher shortages (2018) already experienced, particularly in primary education, as student numbers grow alongside measures to further expand all-day schooling. But recruitment is challenging; the role is seen as less attractive and increasingly complex. Shortages are also felt in VET, where prospective teachers may earn considerably more elsewhere, and in ECEC, where staff shortages and absences were reported as the two main barriers to effective leadership in TALIS Starting Strong 2018. Indeed, the OECD (2019) noted that expected further growth in ECEC participation, combined with large numbers of staff due to retire in the coming years, have led to a potential estimated shortfall of around 200000 ECEC staff by 2030 .

Working conditions for school teachers in Germany include above-average teaching hours, around average class sizes, and more competitive salaries compared to their peers in other countries. For example, at lower secondary level, teachers in Germany taught 744 hours $^{7}$ in 2018 (compared to an OECD average of 709 hours). In 2017, the average class size at that education level was 24 students (similar to the OECD average of 23), and teachers earned the same as the average full-time, full-year, tertiary-educated worker in Germany (compared to an average relative share of $88 \%$ across the OECD). Starting salaries are particularly high in Germany; primary and upper secondary teachers earn around double the OECD average at the start of their careers, although salary scales are more compressed than elsewhere. In the ECEC sector, teacher-child ratios are low: in 2017 there was 1 teacher to 9 children in pre-primary education in Germany, compared to 1 to 14 on average. However, pre-primary teachers had $70 \%$ more teaching hours per year in 2017 than the OECD average.

\section{Key strengths and challenges in ECEC and school improvement}

\section{Key strengths}

- Some PISA data suggests positive views from students on their learning environments.

- Teacher salaries in Germany have been among the highest across the OECD.

\section{Key challenges}

Supporting school leaders in raising standards by redefining their role and improving training. Maintaining a strong supply of highly qualified teachers, especially for primary and ECEC. 


\section{4 | No. 16 - EDUCATION POLICY OUTLOOK IN GERMANY}

\section{Recent policies and practices}

In 2019, the federal government and the Länder approved a joint initiative to support disadvantaged schools (Schule macht stark, 2021-30). It aims to improve educational opportunities for disadvantaged students by enhancing teaching and school development, as well as schools' collaboration with local partners and school networking. Recognising that disadvantage is contextually specific, an interdisciplinary research cluster funded by the federal government will support primary and lower secondary schools to identify their own development needs and craft responsive projects. The Länder invite or nominate schools to participate based on nationally determined indicators of disadvantage; 200 schools will participate.

The national programme to enhance the quality of teacher training (Qualitätsoffensive Lehrerbildung, 2014-23), is a funding competition scheme to strengthen initial teacher preparation (ITP) and raise the attractiveness of teaching. This includes improving the structure of ITP, bridging the theory-practice divide, and offering more targeted support and explicit training for dealing with inclusion in the classroom. In the first phase (2015-18), 59 universities across Germany with ITP programmes received funding for 49 projects. An interim review (2018) praised the funding model as helping universities of ITP to critically reflect and enhance their organisation and collaboration. Furthermore, the flexibility of the programme enabled universities of ITP to adapt to their respective contexts. However, some topics had not yet been sufficiently addressed, including digitalisation, VET provision, teacher shortages and internationalisation. This informed phase two (2019-23) and new funding streams for the digitalisation of ITP and VET-specific ITP were introduced. The programme currently funds 92 projects at 72 universities.

Germany launched the Qualification of pedagogical specialists for inclusive education (2016), which aims to better orient and prepare pedagogical specialists in all educational sectors for inclusive teaching and learning. The initiative funds 39 research projects, 18 of which are collaborative efforts, in universities across the country. Research topics include inclusive education methods as well as impact. An accompanying overarching project looks to integrate the results and promote networking among researchers.

The federal programme, Skilled Labour Initiative: Attracting New Talent, Retaining Professionals (2019-22) focuses on strengthening three areas for ECEC staff: 1) expanding places for paid, practice-integrated vocational training and apprenticeships; 2) improved professional guidance for student teachers; and 3 ) better professional and financial prospects. Within the first action line, the federal government funded 2500 study places on paid, practical vocational programmes. With strong interest, these places were oversubscribed in the first year.

Given teacher shortages and growing refugee numbers, some local initiatives aim to help refugee teachers enter the education system. In 2015, the University of Potsdam's Refugee Teachers' Programme offered language instruction, theoretical seminars and practical school-based sessions over three semesters. On completion, participants received a one-year assistant teacher contract. An interim evaluation (2018) noted the perceived attractiveness of the programme and the co-operation between various actors but highlighted the challenges posed by language skills and validation or recognition of previous qualifications. Similar programmes have since appeared elsewhere in Germany but remain small in scale. The Länder are responsible for recognising teacher qualifications acquired abroad (based on national regulations to implement European directives). However, key guidelines from KMK on foreign teacher qualifications, as part of regulated professions for refugees, aim to promote coherence.

Figure 5. The learning environment according to students, PISA 2018

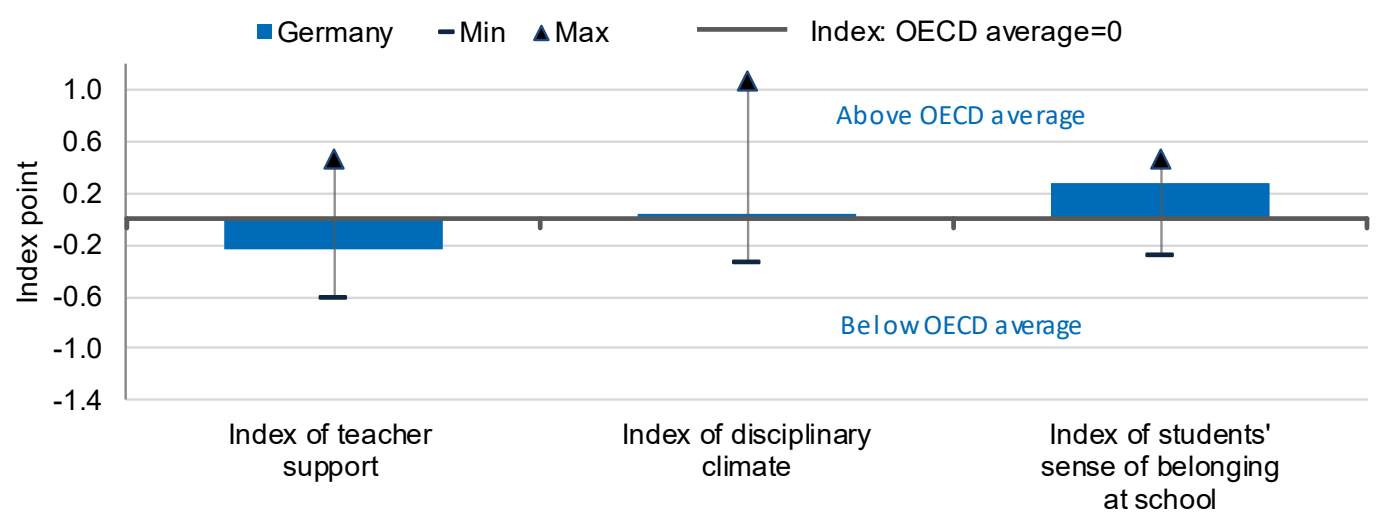

Note: "Min"/ "Max" refer to OECD countries with the lowest/highest values

Source: OECD (2020), PISA 2018 Results (Volume III): What School Life Means for Students' Lives, PISA, OECD Publishing, Paris, https://doi.org/10.1787/acd78851-en. 


\section{EVALUATION AND ASSESSMENT: SYSTEM-LEVEL EVALUATION IS BEING STRENGTHENED}

Defining strategies for evaluation and assessment is an important step towards improving student outcomes and developing a better, more equitable, school system. System evaluation can provide evidence to help decisionmakers craft informed policies and increase the transparency of system outcomes. In Germany, evaluation culture has been moving away from regulatory and professional control towards improvement-focused monitoring. At federal level, common education standards (2004) facilitate the comparison of outcomes across Länder through sample-based National Assessment Studies, occurring at regular intervals in primary and lower secondary education. The results inform national reports (IQB-Bildungstrend). Annual state-wide assessments for students in grades 3 and 8 (VERA, 2006) also help to assess competencies achieved by students at specific points in their education. Individual and school-level results are not made public, nor used for comparison across Länder, but are reported to schools to foster school and teaching development. The independent Institute for Educational Quality Improvement (IQB, 2004) oversees this. In ECEC, system-level evaluation remains limited as responsibility for monitoring lies with providers; the OECD (2018) reported that such an approach may be insufficient. However, some recent efforts have been introduced at both federal and Länder level (see "Recent policies and practices").

Systematised school evaluation processes are relatively new to Germany although, by 2008, all Länder had implemented external evaluation procedures. Approaches differ, but all adhere to national quality standards and occur every three to six years. These external evaluations are improvement-focused; schools are not obliged to act on results. School self-evaluations also have a growing role: school leaders are expected to develop school-specific profiles against which the school internally monitors its performance with support and oversight from the school supervisory authorities of each Länder. An analysis of educational accountability (2016) stated that the latter's role, which previously focused on legal compliance, is increasingly oriented towards supporting schools in interpreting monitoring data, and advising on development planning. These processes also consider actions of the school management. Moreover, some Länder have also introduced official evaluation procedures for school leadership teams. At ECEC level, providers are generally responsible for decisions regarding the frequency of evaluation, what should be monitored and by whom. In TALIS Starting Strong 2018, a larger share of German ECEC leaders reported not receiving external evaluation at least once a year than in most other participating countries.

OECD analysis has found that teacher appraisal can strengthen professionalism and performance, provided it includes an improvement component emphasising developmental evaluation and a career progression component. Germany was the only high-performing country in PISA 2015 with no nationally-legislated appraisal policy; however, as civil servants, teachers are mandatorily appraised at specific moments in their career, such as the end of the probationary period. Legal regulations and procedures for appraisal vary across the Länder, with teacher unions involved in some cases. Furthermore, in Germany, the Standards for Teacher Training: Educational Sciences (2004, revised in 2019), clarify the key expectations for the teaching profession, which are organised into four areas: teaching, education, assessment and innovation. In PISA 2015, 88\% of students were in schools where teaching practices were reported to be monitored through classroom observation by the principal or senior staff (compared to $81 \%$ across the OECD). Teacher peer reviews were reported to a lower extent, however, with $45 \%$ of students in schools whose principals reported their use, compared to $66 \%$ on average.

The extent and ways in which a system uses student assessment can vary depending on need, however, strong student assessment is important in generating data and processes to stimulate education improvement. As well as the national standardised assessments described above, students in Germany sit examinations at the end of upper and lower secondary schooling. Traditionally teacher-set examinations, there are now growing efforts to achieve greater comparability: most Länder have now introduced state-wide examinations to provide comparable data at the Länder level and these are mutually recognised between Länder. Furthermore, in 2017, for the first time, a joint pool of tasks provided by the IQB was used for some examinations within the Abitur. At the same time, in PISA 2015, Germany had smaller than average shares of students whose principal reported that standardised tests were used either to make decisions on students' promotion or retention (13\% compared to $31 \%$ ) or to identify instruction or curriculum areas that could be improved (14\% compared to 59\%). In PISA 2018, students themselves reported low levels of teacher feedback on their learning with an index of -0.07 compared to 0.01 on average.

\section{Key strengths and challenges in evaluation and assessment}

\section{Key strengths}

- Germany has strengthened its system and school-level evaluation components to increase national comparability and the improvement focus.

- There are nascent efforts to ensure comparability in student examinations across the Länder.

\section{Key challenges}

- Strengthening the evaluation and assessment system within ECEC to drive quality provision.

- Fostering a culture of using student assessment data to improve teaching and learning and school performance. 


\section{6 | No. 16 - EDUCATION POLICY OUTLOOK IN GERMANY}

\section{Recent policies and practices}

In an effort to improve education quality based on data across the different Länder, the Standing Conference of the Ministers of Education and Cultural Affairs (KMK) adopted a Global Strategy for education monitoring (2006). The strategy covers four interconnected areas: 1) international comparative studies of student achievement; 2) central assessment of the achievement of educational standards (the basis for comparison between the Länder); 3) comparative studies to review the efficiency of individual schools within the Länder; and 4) joint education reporting of the Federation and the Länder. With a later revision (2015), the KMK aimed to move beyond only describing developments in the education sector to improving the quality of conclusions drawn from empirical data, and implementing change accordingly. As part of this strategy, in 2012, the KMK adopted educational standards for the general higher education entrance qualification (Allgemeine Hochschulreife) for a few subjects (German, mathematics, English and French). Students first sat the exams based on these standards in the school year 2016/17.

As part of the Good Daycare Facilities Act (Gute-KiTa-Gesetz, 2019) (see "Equity and Quality") the Federal Ministry for Family Affairs, Senior Citizens, Women and Youth (BMFSFJ) is conducting nationwide and Länder-specific quality monitoring processes. Specifically, the focus is on supporting the monitoring processes which are a condition of the funding allocations made through the Act. To this end, a dedicated secretariat (Geschäftsstelle, 2019) has been established within the BMFSFJ. The secretariat supports the Länder in developing action plans and progress reports for the implementation of the Act and promoting cross-Länder exchange on developing more process-oriented monitoring and evaluation procedures for the ECEC sector. The BMFSFJ will publish monitoring reports annually from 2020-23.

In ECEC, some Länder-level monitoring processes have been developed in recent years. In 2010, Berlin introduced mandatory external evaluation for all ECEC settings on a five-year cycle. External evaluators consider the perspectives of the ECEC provider, management, individual staff and parents. Evaluators use interviews or written questionnaires and include observations on, for example, material resources as well as on interactions between children and staff. They then provide ECEC settings with professional feedback on pedagogical processes, organisation and staff co-operation, and parental engagement, as well as concrete recommendations for further quality development. Results are only made publicly available at the provider's discretion. The Institute for quality Development (Berliner Kita-Institut für Qualitätsentwicklung) coordinates this process, which complements the annual internal evaluations in place since 2008. An evaluation of the mandatory external evaluations (2017) found that staff reported improved quality in ECEC in Berlin since 2008, although other quality-focused initiatives were introduced over that time, and external evaluations appear to have strengthened appreciation of the profession, as well as their self-perception of their work. However, there have been some challenges regarding the use of the collected data and the practical implementation of quality requirements. Following pilot evaluations in 2019 , from 2020 all ECEC settings in Hamburg will receive external evaluation, also over a five-year cycle. The results will not be published but should be available to parents. If relevant, inspectors will agree on improvements with the provider and set binding deadlines.

Figure 6. Percentage of students in schools where the principal reported assessments of students in national modal grade for 15-year-olds, PISA 2015

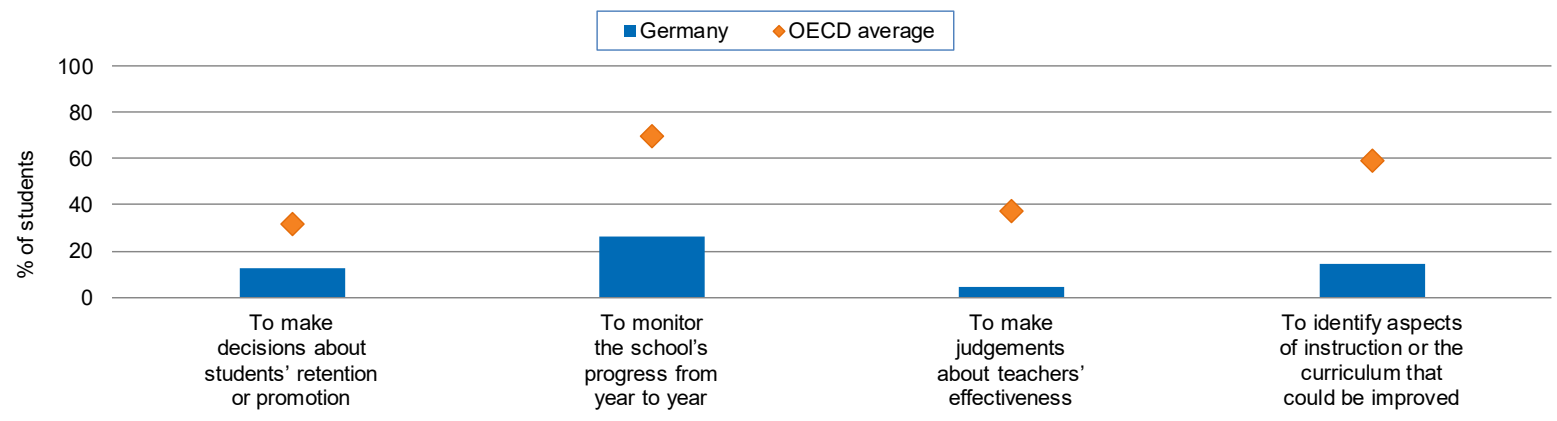

Source: OECD (2016), PISA 2015 Results (Volume II): Policies and Practices for Successful Schools, PISA, OECD Publishing, Paris, http://dx.doi.org/10.1787/9789264267510-en. 


\section{GOVERNANCE: A WELL-ESTABLISHED STRUCTURE OF ENGAGEMENT WITH SUB-NATIONAL ACTORS}

Education in Germany is jointly governed by the 16 Länder and the federal government. The Länder have their own education ministries and are responsible for ECEC, schools, higher and adult education. They can legislate, except where the Basic Law awards legislative powers to the Federation. The Federal Ministry of Education and Research (BMBF) steers national policy for VET and aspects of tertiary education. The ECEC sector is governed through the Federal Ministry of Family Affairs, Senior Citizens, Women and Youth (BMFSFJ) and corresponding Länder-level ministries. Part-time VET schools in the dual system and full-time VET schools are under the authority of the Länder, while other VET provision is governed centrally. Other bodies shaping education policy include:

- The Standing Conference of the Ministers of Education and Cultural Affairs of the Länder (Kultusministerkonferenz) supports co-operation by coordinating policies and making recommendations.

- The Federal Institute for Vocational Education and Training (Bundesinstitut für Berufsbildung) is a government institution for policy, research and practice and a major instrument for co-operation between the various stakeholders in the VET sector.

- The Institute for Quality Development in Education (Institut zur Qualitätsentwicklung im Bildungswesen, 2004) supports the Länder to strengthen the quality of education, particularly through quality assurance.

- The German Institute for Adult Education (Deutsches Institut für Erwachsenenbildung) receives federal and Länder funding for research on a range of issues related to lifelong learning and continuous education.

Some actors play an important role in education policy in Germany, due, in part, to the country's corporatist tradition. They include teachers' unions such as the Trade Union of Education and Science, which represents educational professionals across all levels of the system; the German Rectors' Conference, a voluntary association of 267 universities; and the German Adult Education Association, which represents over 900 adult education centres. In the VET sector, social partners are involved at all levels, according to the principle of consensus. This largely occurs through the Federal State Boards and the VET Committees of the Chambers.

In ECEC, national and Länder authorities are responsible for setting minimum standards, such as space requirements, staff qualifications and child-staff ratios. The Länder develop their own curricula based on a national Common Framework for Early Education. Non-state providers, generally non-profit, run most settings: a national education evaluation (2018) reported that in $2017,69 \%$ of children under 3 and $65 \%$ of $3-5$ year-olds attended such settings. ECEC providers appear to have considerable autonomy: in TALIS Starting Strong 2018, at just over 3\%, the share of German ECEC centre leaders reporting that the local, regional or national authorities had significant responsibility in making decisions regarding staff appointment or dismissal was the second-smallest among participating countries.

In Germany, most schooling decisions are taken by the Länder, which have authority over the organisation, planning, management and supervision of the entire school system, as well as teacher recruitment and remuneration. According to administrative data, in $2017,63 \%$ of decisions in lower secondary education were under the responsibility of the Länder, compared to $10 \%$ at state level on average across the OECD. This was also a larger share than in other federal systems such as Australia (48\%) and Canada (33\%) where more authority is devolved to either local administrations or schools. German schools have relatively limited autonomy, with responsibility for only $17 \%$ of educational decisions - this is half the OECD average share. Different actors are involved in school-level decision-making through the teachers' conference and the school conference. The latter involves representatives from school leadership, teachers, students, parents and the local community and takes decisions related to homework, events and the organisation of school life.

Higher education in Germany is also governed by the Länder. Although each higher education institution (HEI) has a considerable amount of autonomy, there is some variation between the Länder, both in terms of legislation and standard practice. Institutional management has been strengthened through the introduction of institutional governing boards comprised by external representatives which advise and exert some control over management teams and academic senates. However, in most cases, the traditionally strong academic senates maintain authority over aspects related to human and general resource management. In order to balance institutional autonomy with policy coherence, the Länder conduct multi-annual target agreements negotiated with HEI.

\section{Key strengths and challenges in governance}

\section{Key strengths}

- Several actors at sub-national level are involved in decisionmaking, particularly in VET.

- Germany has been working to strengthen institutional governance within higher education.

\section{Key challenges}

- Balancing schools' capacity to respond to local needs within a system where decision-making responsibility is focused at the Länder level. 


\section{8 | No. 16 - EDUCATION POLICY OUTLOOK IN GERMANY}

\section{Recent policies and practices}

BMBF leads the national implementation of UNESCO's Global Action programme on Education for Sustainable Development (ESD GAP, 2015-19). To facilitate this across all sectors, since 2015, the BMBF chairs a biannual national platform that brings together over 300 decision makers from politics, research, the private sector and civil society. Six expert panels (on the topics of ECEC, schools, VET, higher education, informal and non-formal learning and local authorities), eight partner networks and a youth forum are linked to the platform. In 2017, the National Platform ESD adopted the National Action Plan for ESD, which has 130 short-, mid- and long-term objectives covering all educational areas. This is the first plan for ESD endorsed by the Federal Government, the Länder, local authority organisations, economic organisations, civil society and academics working in related areas. One goal, among others, is to examine further implementation strategies of ESD in education and to develop recommendations in order to support the federal states in including ESD further on different educational levels. The implementation process undergoes constant evaluation and the government reports progress on each legislative period.

In order to create sustainable local structures for educational monitoring and management, the Local Learning programme (Lernen vor Ort, LvO, 2009-14), jointly-funded by the federal government and the European Social Fund, brought together education experts from 40 districts and cities, and more than 180 local foundations. LvO helped to establish innovative concepts of local educational governance. Capitalising on the success of the programme, the federal government launched a transfer initiative for municipal education management (Transferinitiative Kommunales Bildungsmanagement, 2014-22) in order to extend the results of the programme to municipalities across the country. A nationwide network of nine transfer agencies (Transferagenturen) offers advice to local authorities drawing on successful models and concepts developed during LvO. In addition, a second transfer initiative programme (Bildung integriert, 2015-22) complements the work of the transfer agencies and supports the local implementation of educational governance systems. Co-financed by the European Social Fund, the programme provides support to more than 130 cities and districts. Beyond that, between 2016 and 2021 the transfer initiative approach was successfully employed in order to support 321 local governments (80\% of districts and cities in Germany) in their attempts to co-ordinate and optimise educational offers for immigrants.

The German Accreditation Council (2017) is Germany's first joint institution of the Länder for quality assurance in higher education. It represents a concerted effort to establish a single common accreditation system for all tertiary institutions in Germany. The Accreditation Council is responsible for the accreditation of both study programmes and quality assurance systems. This is done on the basis of reports and assessment recommendations by accreditation agencies, which are commissioned by the higher education institutions. The aim is to help foster equivalency across the country but also internationally, particularly in the common European education area.

\section{Figure 7. Percentage of decisions taken at each level of government for public lower secondary schools (2017)}

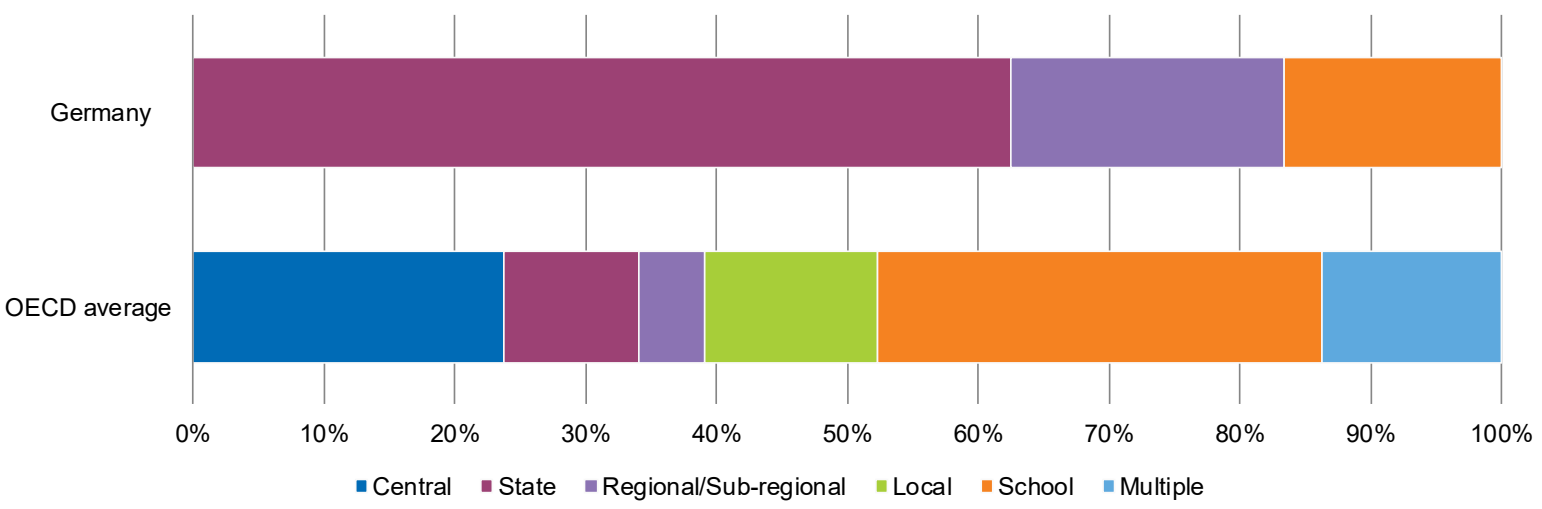

Note: This figure considers four domains of decision-making: 1) Organisation of instruction; 2) Personnel management; 3) Planning and structures, and; 4) Resources.

Source: OECD (2018), Education at a Glance 2018: OECD Indicators, OECD Publishing, Paris, https://doi.org/10.1787/eag-2018en. 


\section{FUNDING: HIGH SPENDING, WITH GROWING PRESSURE AS STUDENT NUMBERS RISE ACROSS THE SYSTEM}

In 2016, Germany's overall expenditure on education (primary to tertiary) as a proportion of national wealth was below the OECD average, at $4.2 \%$, compared to $5 \%$. However, Germany's per-student spending remains higher than the OECD average at every level of education. The most notable differences were in vocational upper secondary education (where Germany spent USD 16323 compared to USD 10922 on average across the OECD), pre-primary education (USD 10101 per student compared to USD 8 349) and tertiary (USD 17429 compared to USD 15556). However, at tertiary level, a much larger share of expenditure is dedicated to research and development (R\&D) than on average across the OECD. Spending at this level has also not kept up with growth in student numbers and so, between 2010 and 2016, per-student spending at this level actually decreased by $13 \%$, compared to an OECD average increase of $8 \%$. In 2018, as high birth and immigration rates result in a growing student population across the system, the OECD (2018) reported that the government had made education a spending priority.

As elsewhere in the OECD, the majority of funding for education institutions (primary to tertiary) in Germany came from public sources in 2016 , at $86 \%$, compared to an OECD average of $83 \%$. However, whereas private spending on tertiary education in Germany is well below average (17\% compared to $34 \%$ ), at primary and secondary level it is larger than average (13\% compared to 10\%). Between 2010 and 2016, the relative share of public expenditure from primary to tertiary education declined by 1 percentage point, compared to a 3 percentage-point decline across the OECD. Private contributions are highest in ECEC, where one-fifth of funding is covered by households, although this is in line with the OECD average. Unusually, OECD (2017) evidence also indicates that nearly $10 \%$ of all private funding at this level comes from non-profit organisations; this is increasingly seen as an important policy lever for sectoral expansion. The Länder regulate the additional charges for ECEC, and a growing number have both fully or partially abolished fees for certain age groups, and introduced needs-based waivers (see "Recent policies and practices"). The federal government has also allocated additional resources to the Länder and local authorities (Kommunen) responsible for the provision of ECEC in their territory in order to support increases in enrolment in ECEC. In VET, vocational training that occurs outside schools is generally financed by companies.

In Germany, the majority of funding for primary and secondary schools comes from the Länder. In 2016, the federal government provided $7 \%$ of initial funds for primary to post-secondary non-tertiary education while the Länder and local authorities provided $75 \%$ and $18 \%$ respectively. The Länder fund teacher salaries, while the Kommunen cover compensation for non-teaching staff and material costs, although they may receive one-off transfers from the Länder for the latter. Constitutional rules limit the role of federal spending on ECEC and compulsory education; the OECD (2018) recommended removing such barriers given the nationwide benefits of extending and improving educational provision at these levels. A recent amendment to Germany's Basic Law enables co-funding to now take place in certain areas regarding digitalisation (see Spotlight 4) and the Good Daycare Facilities Act. There are funding disparities between the Länder: in 2016, annual expenditure per student ranged from USD 10100 to USD 13 500. The EC (2019) reported that education shortfalls at municipal level now constitute the largest share of investment needs. At school level, school leaders' reports in PISA 2018, suggest that shortages in educational material hinder student learning to a greater extent than on average with an index of 0.31 compared to 0.00 on average. Constraints on the financial autonomy of schools are gradually being relaxed: in most Länder, schools now have responsibility for budgetary decisions related to teaching and learning, for example.

In tertiary education, $78 \%$ of final funds for education at this level in Germany came from the Länder, while $20 \%$ was provided by the federal government and the remaining $2 \%$ came from the Kommunen in 2016 . By way of comparison with other OECD countries, on average $83 \%$ of final funds came from the central level, while $16 \%$ of funds came from the regions, and only $1 \%$ came from the local level during the same year. HEls in Germany receive their funding in a lump sum and therefore have considerable budgetary responsibility and financial autonomy, although many Länder require HEls to submit annual spending plans for approval. Nearly all Länder use performance-based indicators to determine a small share of tertiary funding. In general, no tuition fees exist in Germany, but students have to pay a small fee (Semesterbeiträge) to the respective student services (Studierendenwerk).

\section{Key strengths and challenges in funding}

\section{Key strengths}

- Fees for ECEC are increasingly being abolished across the Länder.

- Funding per student is above OECD average in Germany, particularly in ECEC, VET and tertiary education

\section{Key challenges}

- Ensuring that funds predominantly raised at state and local level can keep up with growing student numbers across the system.

- Mitigating resource shortages at institutional level, as well as disparities between regions. 


\section{0 | No. 16 - EDUCATION POLICY OUTLOOK IN GERMANY}

\section{Recent policies and practices}

Following Germany's Childcare Funding Act (2008), four investment programmes aim to support ECEC growth. The federal government provided EUR 3.28 billion in the first three investment programmes and 400000 new places for children under three had been created by 2018. The fourth investment programme (2017-20) aims to support up to 100000 additional ECEC places for children up until school age with an allocation of EUR 1126 billion.

As part of the Good Daycare Facilities Act (see "Equity and Quality"), from 2019, parental contributions to ECEC must be staggered, and recipients of certain social supports must be exempted. The Act supports Länder in achieving this by enabling them to invest additional federal funds as they see fit. Many have decided to use part of the money to reduce or even abolish parental contributions. Several Länder had already introduced measures to reduce the cost of ECEC to families without federal contributions. Some Länder have fully abolished contribution fees for all age groups: Hamburg (2014, for up to 30 hours a week); Mecklenburg-Western Pomerania (law passed, implementation as of 2020). Others abolished fees for some age groups: Rhineland-Palatinate (2010, from age 2); NorthRhine Westphalia (2011, the last year before school); and Lower Saxony (2018, from age 3 to school entry, 8 hours a day). Others lowered (Saarland, Bavaria) or capped (Schleswig-Holstein) fees. However, The EC (2018) reported that, as of 2018, unsatisfied demand and demographic change will create need for over 600000 more places by 2025 and that issues persist around service quality and flexibility.

The Excellence Strategy (2019) is a joint measure between the federal government and the Länder to raise the quality of research. It has two funding lines: Excellence Clusters (project-specific funding for 7 years) and Universities of Excellence (institution-focused permanent funding for universities hosting multiple Clusters). The total annual budget is set at EUR 533 million with a federal contribution of $75 \%$, and $25 \%$ from the Länder. Funding for the first 57 Excellence Clusters began in early 2019. Funding for ten Universities of Excellence and one Excellence Alliance consisting of three universities began in late 2019. The Excellence Strategy follows the successful Excellence Initiative (2007-17) which aimed to develop high-performing researchers and raise the attractiveness of Germany as a location for research. In 2016, an expert commission reported that the Initiative made the German university system more dynamic and internationally competitive, having fostered strategic institutional profiling.

In Berlin, the Bonus programme (2014) provides additional funds to disadvantaged schools. To receive funding, disadvantaged schools, determined by the socio-economic composition of the student body or local area, develops a performance agreement with the inspectorate. The first cohort included 220 primary and secondary schools which received EUR 50 000-100 000 each, according to the level of disadvantage. A performance-based component is awarded if the school meets its targets; the share of total funding fulfilled by this component increases gradually. An interim report (2016) found principals felt positively about targeted financing and support to manage heterogeneity but less positively about the built-in increases in the performance-based component and the administrative burden

\section{Figure 8. Annual expenditure per student (2016) and recent trends, by level of education}

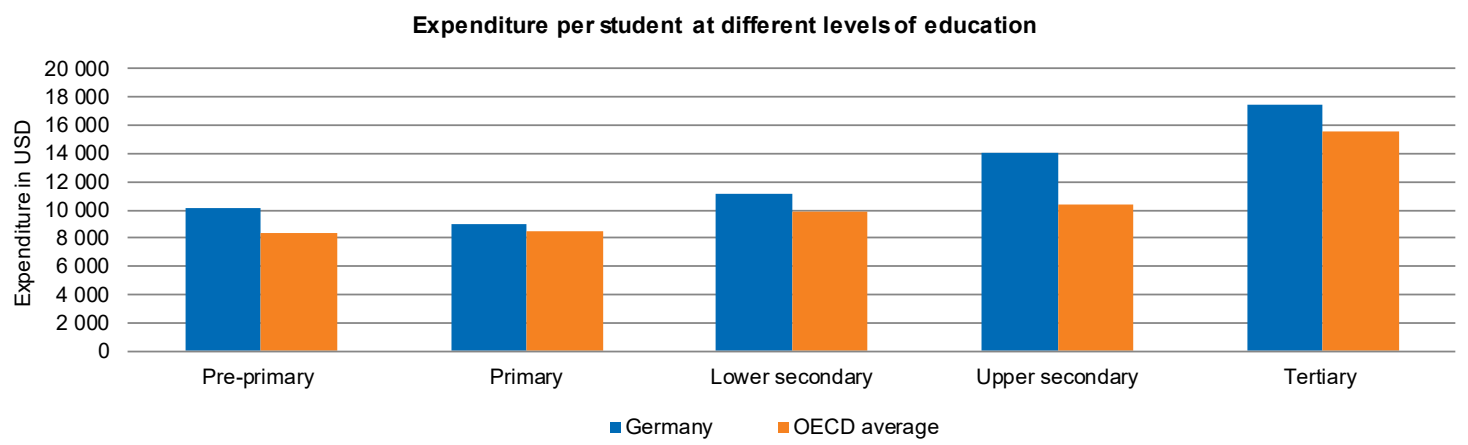

Change in expenditure per student, primary, secondary and post-secondary non-tertiary education $(2010=100)$

Change in expenditure per student, tertiary education $(2010=100)$
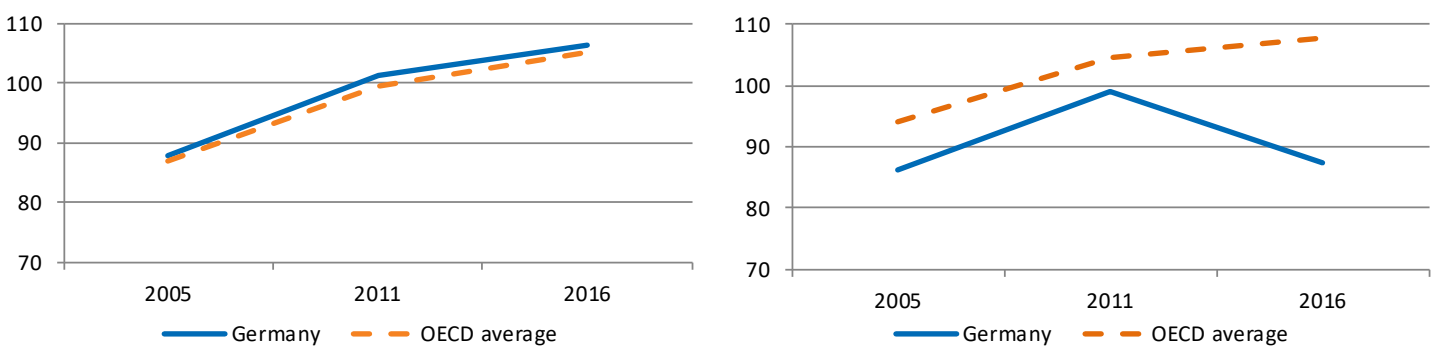

Source: OECD (2019), Education at a Glance 2019: OECD Indicators, OECD Publishing, Paris, https://doi.org/10.1787/f8d7880d-en. 


\section{Spotlight 4. The Digital Pact for Schools: a new approach to educational funding}

The Digital Pact for Schools (DigitalPakt Schule, 2019) aims to equip students with the digital skills required for success in the $21^{\text {st }}$ century. This entails establishing the necessary digital infrastructure in schools, as well as developing pedagogical content and curricula to equip children with digital skills, and redesigning initial teacher preparation and continuous professional development to strengthen teachers' digital competencies. The Digital Pact encompasses novel legal, financial and governance-related components, allowing the federal government to financially support educational initiatives in the Länder, in a way that was previously not feasible. It thus carries important symbolic weight.

\section{- Broader legal foundation}

Prior to the Digital Pact, German legislation only afforded the federal government the right to fund sub-national educational initiatives in support of "financially weak" municipalities - and this only since 2017. The massive, nationwide investment in digital infrastructure required as part of the Digital Pact, thus called for an innovative arrangement which both ensured sufficient financial support for a key policy priority, and protected the cultural sovereignty of the Länder in the area of education.

To this end, the German Parliament reached an agreement to amend Art. 104c of the German Basic Law, enabling better cooperation between the federal level and the Länder by granting the federal government the legal right to offer financial support to the Länder in improving municipal education infrastructure in "areas of significance to the nation as a whole, and for special limited-term expenditures". As such, this legal right goes beyond the scope of the Digital Pact and may be employed for future initiatives as well.

\section{- Governance}

Following the legislative amendment, the federal government and the Länder signed an administrative agreement establishing governance arrangements for the Digital Pact. The Länder are in charge of all administrative elements, including the development of pedagogical plans, enhancing teachers' competencies and maintaining the digital infrastructure. Knowing that the Pact only defines the foundations for a national digital infrastructure for schools, but cannot meet all the needs of individual schools, the Länder may also establish complementary state-level programmes. All such efforts should be steered from the centre by aligning with the KMK's Education in the Digital World strategy (2016).

The funding aims to be locally responsive. Individual schools must develop their specific media educational plans (Medienkonzept) establishing how digital tools will be used in the classroom. From this, schools can better determine their digital equipment needs and then apply for the appropriate financial support through the local education authority. These applications are then synthesised and submitted to the designated Länder-level body which evaluates, approves and assigns funds.

The Digital Pact hopes to have a lasting structural impact on education governance through the introduction of regional, national and transnational innovations regarding the operation, service and maintenance of the digital infrastructure. Such cross-border projects may also stimulate shared standards for digital learning opportunities or shared educational infrastructures such as school clouds.

\section{- Funding}

In total, the federal government will provide EUR 5 billion in financial support to the Länder (2020-24). This is matched by an additional financial contribution by the Länder of EUR 550 million. While the administrative agreement established key rules for applying for and carrying out the funding, state-specific funding conditions and guidelines were then developed by each Land. As such, allocation models differ and may include core funding per school, per-student allocations, or differentiated allocations by school type. 
ANNEX A: STRUCTURE OF GERMANY'S EDUCATION SYSTEM

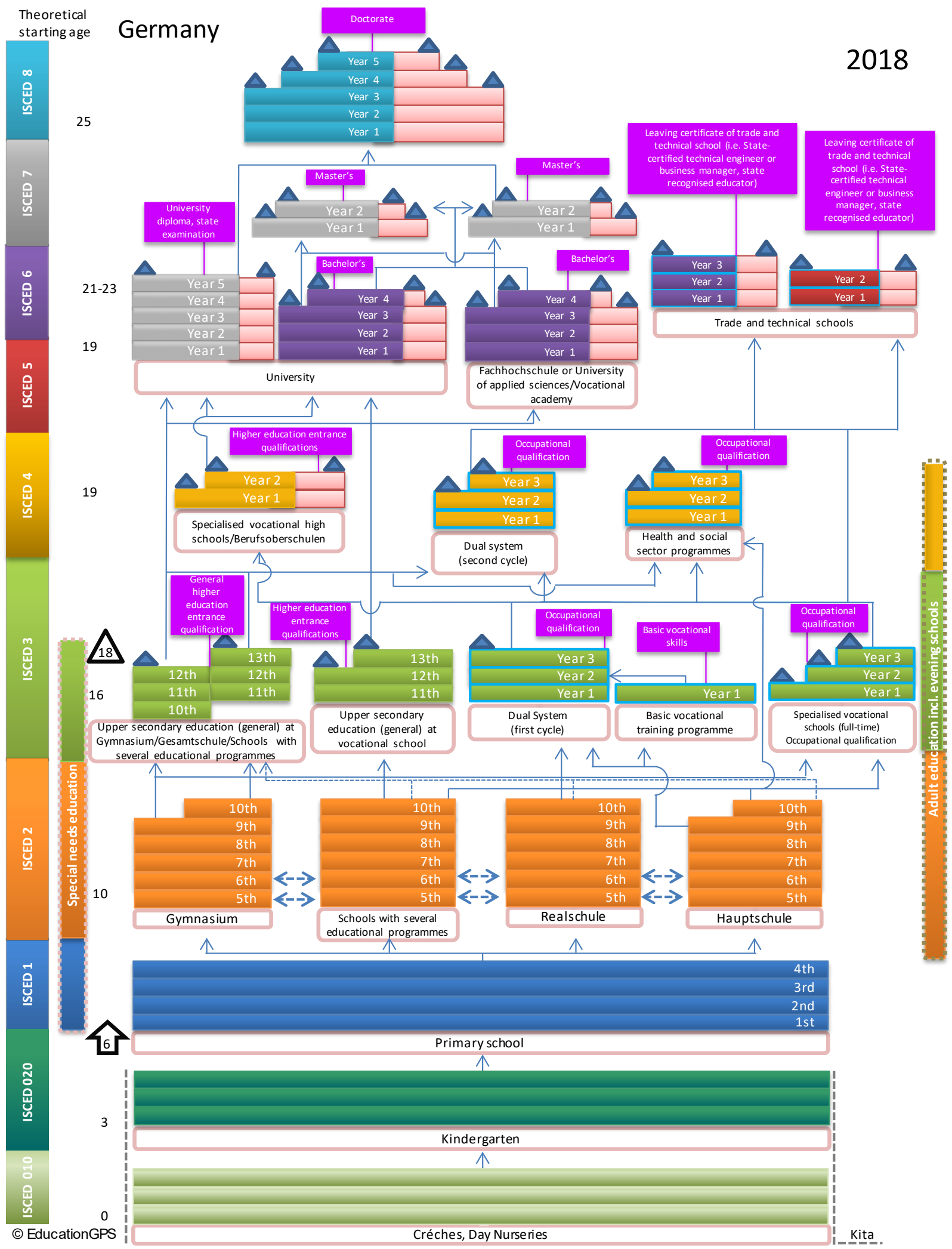

Note: The key for the interpretation of this table is available at the source link below.

Source: OECD (2018), "Germany: Overview of the Education System", OECD Education GPS, http://gpseducation.oecd.org/Content/MapOfEducationSystem/DEU/DEU 2011 EN.pdf. 


\section{ANNEX B: STATISTICS}

\begin{tabular}{|c|c|c|c|c|c|}
\hline$\#$ & List of key indicators ${ }^{1,2,3}$ & Germany & $\begin{array}{l}\text { Average } \\
\text { or total }\end{array}$ & $\begin{array}{l}\text { Min } \\
\text { OECD }\end{array}$ & $\begin{array}{l}\text { Max } \\
\text { OECD }\end{array}$ \\
\hline \multicolumn{6}{|c|}{ Background information } \\
\hline \multicolumn{6}{|c|}{ Economy } \\
\hline 1 & $\begin{array}{l}\text { GDP per capita, 2016, in equivalent USD converted using PPPS (OECD } \\
\text { Statistics) }\end{array}$ & 49516 & 42441 & 14276 & 107775 \\
\hline 2 & GDP grow th, 2016 (OECD Statistics) & $2.2 \%$ & $1.8 \%$ & $0.6 \%$ & $6.6 \%$ \\
\hline \multicolumn{6}{|c|}{ Society } \\
\hline 3 & Population density, inhab/km², 2017 (OECD Statistics) & 234 & 37 & 3 & 517 \\
\hline 4 & $\begin{array}{l}\text { Population aged less than } 15 \text { as a percentage of total population, } 2018 \\
\text { (OECD Data) }\end{array}$ & $13.5 \%$ & $17.0 \%$ & $12.2 \%$ & $28.4 \%$ \\
\hline 5 & $\begin{array}{l}\text { Foreign-born population as a percentage of total population, } 2018 \text { or the } \\
\text { most recent available year (OECD Data) }\end{array}$ & $16.0 \%$ & $14.4 \%$ & $0.8 \%$ & $47.6 \%$ \\
\hline \multicolumn{6}{|c|}{ Education outcomes } \\
\hline 6 & Mean performance in reading (PISA 2018) & 498 & 487 & 412 & 523 \\
\hline \multirow{4}{*}{7} & \multicolumn{5}{|c|}{ Average three-year trend in performance across PISA assessments, by domain (PISA 2018) ${ }^{4,5}$} \\
\hline & Reading performance & 3.3 & 0.4 & -4.9 & 7.1 \\
\hline & Mathematics performance & -0.1 & -0.6 & -9.1 & 6.4 \\
\hline & Science performance & -3.6 & -1.9 & -10.7 & 6.4 \\
\hline 8 & $\begin{array}{l}\text { Enrolment rates of 3-year-olds in early childhood education and care, } \\
2017 \text { (EAG 2019) }\end{array}$ & $91.2 \%$ & $79.3 \%$ & $2.4 \%$ & $100 \%$ \\
\hline 9 & $\begin{array}{l}\text { Percentage of 25-64 year-olds w hose highest level of attainment is } \\
\text { low er secondary education, } 2018 \text { (EAG 2019) }\end{array}$ & $9.7 \%$ & $14.4 \%$ & $0.8 \%$ & $39.9 \%$ \\
\hline \multirow{4}{*}{10} & \multicolumn{5}{|c|}{ Educational attainment of the population aged 25-34 by type of attainment, 2018 or latest available } \\
\hline & At least upper secondary education, 2018 (EAG 2019) & $87.0 \%$ & $85.4 \%$ & $50.1 \%$ & $97.8 \%$ \\
\hline & Tertiary education, 2018 (EAG 2019) & $32.3 \%$ & $44.3 \%$ & $23.4 \%$ & $69.6 \%$ \\
\hline & $\begin{array}{l}\text { Vocational upper secondary or post-secondary non-tertiary education, } \\
2018 \text { (EAG database 2020) }\end{array}$ & $47.2 \%$ & $24.5 \%$ & $1.8 \%$ & $50.1 \%$ \\
\hline \multirow{4}{*}{11} & \multicolumn{5}{|c|}{ Unemployment rates of 25-34 year-olds by educational attainment, 2018 (EAG 2019) } \\
\hline & Below upper secondary & $13.2 \%$ & $13.7 \%$ & $3.0 \%$ & $37.3 \%$ \\
\hline & Upper secondary and post-secondary non-tertiary & $3.4 \%$ & $7.3 \%$ & $2.5 \%$ & $25.1 \%$ \\
\hline & Tertiary education & $2.8 \%$ & $5.5 \%$ & $1.7 \%$ & $23.2 \%$ \\
\hline \multicolumn{6}{|c|}{ Students: Raising outcomes } \\
\hline \multicolumn{6}{|c|}{ Policy lever 1: Equity and quality } \\
\hline 12 & First age of selection in the education system (PISA 2018) & 10 & 14 & 10 & 16 \\
\hline \multirow{3}{*}{13} & \multicolumn{5}{|c|}{ Students performing at the highest or lowest levels in reading (\%) (PISA 2018) } \\
\hline & Students performing below Level 2 & $20.7 \%$ & $22.6 \%$ & $11.1 \%$ & $49.9 \%$ \\
\hline & Students performing at Level 5 or above & $11.3 \%$ & $8.7 \%$ & $0.8 \%$ & $15.0 \%$ \\
\hline 14 & $\begin{array}{l}\text { Percentage of students in schools where students are grouped by } \\
\text { ability into different classes for all subjects, PISA } 2015\end{array}$ & $8.0 \%$ & $7.8 \%$ & $0.0 \%$ & $56.1 \%$ \\
\hline 15 & $\begin{array}{l}\text { Percentage of students whose parents reported that the schooling } \\
\text { available in their area includes tw o or more other schools, PISA } 2015\end{array}$ & $37.4 \%$ & $36.8 \%$ & $20.4 \%$ & $56.9 \%$ \\
\hline
\end{tabular}




\begin{tabular}{|c|c|c|c|c|c|}
\hline$\#$ & List of key indicators ${ }^{1,2,3}$ & Germany & $\begin{array}{l}\text { Average } \\
\text { or total }\end{array}$ & $\begin{array}{l}\text { Min } \\
\text { OECD }\end{array}$ & $\begin{array}{l}\text { Max } \\
\text { OECD }\end{array}$ \\
\hline 16 & $\begin{array}{l}\text { Percentage of students reporting that they have repeated at least a } \\
\text { grade in primary, low er secondary or upper secondary schools (PISA } \\
\text { 2015) }\end{array}$ & $18.1 \%$ & $11.3 \%$ & $0.0 \%$ & $42.6 \%$ \\
\hline 17 & $\begin{array}{l}\text { Percentage of variance in reading performance in PISA test explained } \\
\text { by ESCS (PISA 2018) }\end{array}$ & $17.2 \%$ & $12.0 \%$ & $6.2 \%$ & $19.1 \%$ \\
\hline 18 & $\begin{array}{l}\text { Score difference in reading performance in PISA betw een non- } \\
\text { immigrant and immigrant students AFTER adjusting for socio-economic } \\
\text { status (PISA 2018) }\end{array}$ & -17 & -24 & -80 & 16 \\
\hline 19 & Score difference betw een girls and boys in reading (PISA 2018) ${ }^{4}$ & 26 & 30 & 10 & 52 \\
\hline \multicolumn{6}{|c|}{ Policy lever 2: Preparing students for the future } \\
\hline 20 & $\begin{array}{l}\text { Mean proficiency in literacy among adults aged } 16-64 \text { on a scale of } 500 \\
\text { (Survey of Adult Skills, PIAAC, 2012) }\end{array}$ & 269.8 & 267.7 & 220.1 & 296.2 \\
\hline 21 & $\begin{array}{l}\text { Difference in literacy scores betw een younger (25-34) and older (55- } \\
65) \text { adults AFTER accounting for age, gender, education, immigrant and } \\
\text { language background and parents' educational attainment (Survey of } \\
\text { Adult Skills, PIAAC, 2012). }\end{array}$ & 26.8 & 15.6 & -8.3 & 37.6 \\
\hline \multirow{4}{*}{22} & \multicolumn{5}{|l|}{ Share of students in upper secondary education in 2017 following: } \\
\hline & General programmes (OECD Stat - INES 2020) & $54.4 \%$ & $58.1 \%$ & $27.6 \%$ & $100.0 \%$ \\
\hline & Vocational programmes (OECD Stat - INES 2020) & $45.6 \%$ & $43.1 \%$ & $9.0 \%$ & $72.4 \%$ \\
\hline & Combined school and w ork-based programmes (OECD Stat - INES 2020) & $39.8 \%$ & $18.3 \%$ & $1.0 \%$ & $58.0 \%$ \\
\hline 23 & $\begin{array}{l}\text { First-time graduation rates from tertiary education, } 2017 \text { (Below the age } \\
\text { of } 30 \text {, excluding mobile students / OECD Stat - INES 2020) }\end{array}$ & $32.9 \%$ & $36.6 \%$ & $10.1 \%$ & $49.9 \%$ \\
\hline 24 & $\begin{array}{l}\text { Percentage of } 18-24 \text { year-olds not in education, employment or training, } \\
2018 \text { (EAG 2019) }\end{array}$ & $9.6 \%$ & $14.3 \%$ & $5.9 \%$ & $29.8 \%$ \\
\hline \multicolumn{6}{|c|}{ Ins titutions: Improving schools } \\
\hline \multicolumn{6}{|c|}{ Policy lever 3: School improvement } \\
\hline \multirow{4}{*}{25} & \multicolumn{5}{|l|}{ The Learning Environment - PISA 2018} \\
\hline & Mean index of teacher support in language-of-instruction lessons & -0.24 & 0.01 & -0.61 & 0.47 \\
\hline & Mean index of disciplinary climate & 0.04 & 0.04 & -0.34 & 1.07 \\
\hline & Mean index of students' sense of belonging ${ }^{7}$ & 0.28 & 0.00 & -0.28 & 0.46 \\
\hline 26 & $\begin{array}{l}\text { Percentage of teachers in low er secondary education aged } 50 \text { years } \\
\text { old or more, } 2017 \text { (EAG 2019) }\end{array}$ & $45.9 \%$ & $37.0 \%$ & $6.3 \%$ & $54.2 \%$ \\
\hline \multirow{3}{*}{27} & \multicolumn{5}{|c|}{ Number of teaching hours per year in public institutions by education level, 2018 (EAG 2019) ${ }^{8}$} \\
\hline & Primary education & 800 & 783 & 561 & 1063 \\
\hline & Low er secondary education, general programmes & 744 & 709 & 481 & 1063 \\
\hline 28 & $\begin{array}{l}\text { Ratio of actual teachers' salaries to earnings for full-time, full-year adult } \\
\text { w orkers with tertiary education, low er secondary education, general } \\
\text { programmes, } 2016 \text { (EAG 2019) }\end{array}$ & 1.00 & 0.88 & 0.64 & 1.40 \\
\hline 29 & $\begin{array}{l}\text { Proportion of teachers who believe the teaching profession is valued in } \\
\text { society (TALIS 2018) }\end{array}$ & NP & $25.8 \%$ & $4.5 \%$ & $67.0 \%$ \\
\hline 30 & $\begin{array}{l}\text { Proportion of teachers who w ould become a teacher again if they could } \\
\text { choose (TALIS 2018) }\end{array}$ & NP & $75.6 \%$ & $54.9 \%$ & $92.2 \%$ \\
\hline
\end{tabular}




\begin{tabular}{|c|c|c|c|c|c|}
\hline \multirow[t]{2}{*}{$\#$} & List of key indicators ${ }^{1,2,3}$ & Germany & $\begin{array}{r}\text { Average } \\
\text { or total }\end{array}$ & $\begin{array}{l}\operatorname{Min} \\
\text { OECD }\end{array}$ & $\begin{array}{l}\operatorname{Max} \\
\text { OECD }\end{array}$ \\
\hline & \multicolumn{5}{|l|}{ Policy lever 4: Evaluation and assessment to improve student outcomes } \\
\hline \multirow{3}{*}{31} & \multicolumn{5}{|c|}{$\begin{array}{l}\text { Percentage of students in schools where the following arrangements aimed at quality assurance and improvement at } \\
\text { school are used (PISA 2015): }\end{array}$} \\
\hline & Internal/Self-evaluation & $88.4 \%$ & $93.2 \%$ & $74.8 \%$ & $100.0 \%$ \\
\hline & External evaluation & $72.4 \%$ & $74.6 \%$ & $20.8 \%$ & $97.4 \%$ \\
\hline \multirow{5}{*}{32} & \multicolumn{5}{|c|}{$\begin{array}{l}\text { Percentage of students whose school principals reported that standardised tests are used for the following purposes } \\
\text { (PISA 2015): }\end{array}$} \\
\hline & To make decisions about students' retention or promotion & $12.6 \%$ & $31.3 \%$ & $3.4 \%$ & $60.6 \%$ \\
\hline & To monitor the school's progress from year to year & $26.2 \%$ & $69.4 \%$ & $26.2 \%$ & $97.7 \%$ \\
\hline & To make judgements about teachers' effectiveness & $4.4 \%$ & $37.0 \%$ & $4.4 \%$ & $87.5 \%$ \\
\hline & To identify aspects of instruction or the curriculum that could be improved & $14.1 \%$ & $58.9 \%$ & $14.1 \%$ & $92.4 \%$ \\
\hline 33 & $\begin{array}{l}\text { Percentage of lower secondary teachers whose principals report conducting } \\
\text { formal appraisal of their teachers at least once per year (TALIS 2018) }\end{array}$ & NP & $63.5 \%$ & $16.2 \%$ & $98.1 \%$ \\
\hline \multicolumn{6}{|c|}{ Systems: Organising the system } \\
\hline \multicolumn{6}{|c|}{ Policy lever 5: Governance } \\
\hline \multirow{7}{*}{34} & \multicolumn{5}{|c|}{ Percentage of decisions taken at each level of government in public lower secondary education, 2017 (EAG 2018) } \\
\hline & Central & $0.0 \%$ & $23.8 \%$ & $0.0 \%$ & $83.3 \%$ \\
\hline & State & $62.5 \%$ & $10.3 \%$ & $0.0 \%$ & $62.5 \%$ \\
\hline & Regional/Sub-regional & $20.8 \%$ & $4.9 \%$ & $0.0 \%$ & $33.3 \%$ \\
\hline & Local & $0.0 \%$ & $13.3 \%$ & $0.0 \%$ & $71.9 \%$ \\
\hline & School & $16.7 \%$ & $34.0 \%$ & $0.0 \%$ & $91.7 \%$ \\
\hline & Multiple levels & $0.0 \%$ & $13.8 \%$ & $0.0 \%$ & $100.0 \%$ \\
\hline \multicolumn{6}{|c|}{ Policy lever 6: Funding } \\
\hline 35 & $\begin{array}{l}\text { Expenditure on education as a percentage of GDP (from primary to tertiary), } \\
2016 \text { (EAG 2019) }\end{array}$ & $4.2 \%$ & $5.0 \%$ & $0.0 \%$ & $6.5 \%$ \\
\hline \multirow{6}{*}{36} & \multicolumn{5}{|c|}{$\begin{array}{l}\text { Annual expenditure per student by educational institutions, for all services, in equivalent USD converted using PPPs for } \\
\text { GDP, } 2016 \text { (EAG 2019) }\end{array}$} \\
\hline & Pre-primary education & 10101 & 8349 & 1579 & 17533 \\
\hline & Primary education & 8960 & 8470 & 2961 & 17913 \\
\hline & Lower secondary education & 11159 & 9884 & 2561 & 21739 \\
\hline & Upper secondary education & 14094 & 10368 & 3001 & 21231 \\
\hline & Tertiary education & 17429 & 15556 & 5787 & 48407 \\
\hline \multirow{3}{*}{37} & \multicolumn{5}{|c|}{ Relative proportions of public and private expenditure on educational institutions, 2016 (EAG 2019) } \\
\hline & Public sources & $85.9 \%$ & $82.7 \%$ & $62.7 \%$ & $97.6 \%$ \\
\hline & All private sources (includes international sources) & $14.1 \%$ & $17.4 \%$ & $2.4 \%$ & $37.3 \%$ \\
\hline \multirow{3}{*}{38} & \multicolumn{5}{|c|}{$\begin{array}{l}\text { Change in the share of expenditure on educational institutions, EAG } 2019 \text { (Percentage-point difference between } 2010 \\
\text { and 2016, primary to tertiary education) }\end{array}$} \\
\hline & Public sources & -0.5 & -2.7 & -9.8 & 6.3 \\
\hline & All private sources & 0.6 & 2.5 & -6.3 & 7.0 \\
\hline \multicolumn{6}{|c|}{$\begin{array}{l}\text { Notes } \\
\text { 1. The average, total, minimums and maximums refer to OECD countries except in TALIS } 2013 \text { and the Survey of Adult Skills, where they refer to } \\
\text { indicators } 6,13 \text { and } 17-19 \text { the average value refers to the arithmetic mean across all OECD member countries (and Colombia), excluding Spain. Fo } \\
\text { value refers to the arithmetic mean across all OECD member countries (except Japan, Korea and Poland) as calculated by the Education Policy Ou } \\
\text { 2. "m": included when data is not available. } \\
\text { 3. "NP": included if the country is not participating in the study. } \\
\text { 4. Statistically significant values of the indicator are shown in bold (PISA only). } \\
\text { 5. The average three year trend is the average change in PISA score points from a country's/economy's earliest participation in PISA to PISA } 2018 . \\
\text { 6. "a": included when the category is not applicable. } \\
\text { 7. For Germany, at least } 50 \% \text { but less than } 75 \% \text { of the population was covered in the sample for this indicator. } \\
\text { 8. For Germany, this refers to typical teaching time (teaching time required from most teachers when no specific circumstances apply to teachers). }\end{array}$} \\
\hline
\end{tabular}




\section{REFERENCES AND FURTHER READING}

Accreditation Council Foundation, (2018), State Study Accreditation Treaty, Secretariat of the Accreditation Council Foundation, Bonn, https://www.akkreditierungsrat.de/sites/default/files/downloads/2019/ Studienakkreditierungsstaatsvertrag.pdf.

Ärlestig, H., C. Day, and O. Johansson (eds.) (2016), A Decade of Research on School Principals: Cases from 24 Countries, Studies in Educational Leadership Vol. 21, Springer International Publishing, Basel, https://link.springer.com/book/10.1007/978-3-319-23027-6.

Authority for Labor, Social Affairs, Family and Integration, Hamburg (2019), "Procedures to ensure the quality of day-care centers go into the test phase. First exams start this week", Press Archive - Start of the Daycare Test Procedure, webpage, https://www.hamburg.de/pressearchiv-fhh/13073974/2019-10-15-basfi-kitapruefverfahren/ (accessed 11 June 2020).

Autorengruppe Bildungsberichterstattung (2018), Education in Germany 2018: An Indicator-based Report with an Analysis of the Effects and Benefits of Education, KMK, Berlin, https://www.bildungsbericht.de/de/ bildungsberichte-seit-2006/bildungsbericht-2018/pdf-bildungsbericht-2018/bildungsbericht-2018.pdf.

Bergseng, B., E. Degler and S. Lüthi (2019), Unlocking the Potential of Migrants in Germany, OECD Reviews of Vocational Education and Training, OECD Publishing, Paris, https://doi.org/10.1787/82ccc2a3-en.

Berlin Kita Institute for Quality Development (2020), Home - External Evaluation, Berlin Kita Institute for Quality Development, webpage, https://www.beki-qualitaet.de/index.php/externe-evaluation.html (accessed 29 May 2020).

BMBF (2020), Recognition of Professional Qualifications, BMBF, website, https://www.bmbf.de/en/recognition-offoreign-professional-qualifications-1413.html (accessed 19 June 2020).

BMBF (2019), Bundesprogram - Sprach Kitas - About the Programme, BMBF, webpage, https://sprachkitas.fruehe-chancen.de/ (accessed 29 May 2020).

BMBF (2019), "The federal program: Skilled Labour Initiative: attracting new talent, retaining professionals in ECEC: attracting new talent, retaining professionals", Fachkräfteoffensive Erzieherinnen und ErzieherAbout the Programme, BMBF, webpage https://fachkraefteoffensive.fruehe-chancen.de/programm/ueberdas-programm/ (accessed 29 May 2020).

BMBF (2019), "Interim report of the federal-state steering committee in the federal program Language daycare centers: Because language is the key to the world", Bundesprogram - Sprach Kitas - Programme Evaluation, BMBF, webpage, https://sprach-kitas.fruehe-chancen.de/programm/zwischenbericht/ (accessed 29 May 2020).

BMBF (2019), "InnoVET Competition: Shaping the Future - Innovations for Excellent Vocational Training" Education: Vocational Education: InnoVET Competition, 18 January 2019, BMBF, webpage, https://www.bmbf.de/innovet (accessed 11 June 2020).

BMBF (2018), Vocational Training Report 2018, Federal Publications Office, Rostock, https://www.bmbf.de/upload filestore/pub/Berufsbildungsbericht 2018.pdf.

BMBF (2018), Quality Pact for Teaching in Higher Education, Federal Publications Office, Rostock, https://www.bmbf.de/upload filestore/pub/Gut beraten durchs Studium.pdf.

BMBF (2017), Report on the 2017 Recognition Act, Federal Publications Office, Rostock, https://www.bmbf.de/upload filestore/pub/Bericht zum Anerkennungsgesetz 2017.pdf.

BMBF (2017), "Qualification of pedagogical specialists for inclusive education” Qualifizierung Inklusion - Home Page, BMBF, webpage, https://www.qualifizierung-inklusion.de/ (accessed 29 May 2020).

BMBF (2017), National Action Plan on Education for Sustainable Development: the German Contribution to the UNESCO World Action Program, Berlin, https://www.bmbf.de/files/Nationaler_Aktionsplan_Bildung_f\%C3\%BCr nachhaltige Entwicklung.pdf.

BMBF (2007), Local Learning: Financial Procedures, Berlin, http://www.Ivo.transferinitiative.de/ media/BMBF Foerderrichtlinien Ivo final.pdf.

BMBF (2007), Higher Education Pact, Federal Gazette No. 171, 12 September 2007, p. 7480, BMBF, Berlin, https://www.bmbf.de/files/verwaltungsvereinbarung hochschulpakt2020.pdf. 


\section{7 | No. 16 - EDUCATION POLICY OUTLOOK IN GERMANY}

BMFSFJ (2019), “The Good Kindergarten Law: For Good Daycare Centres Nationwide”, Childcare - More Quality in Early Education - The Good Kindergarten Law, BMBF, webpage, https://www.bmfsfj.de/bmfsfj/themen/ familie/kinderbetreuung/mehr-qualitaet-in-der-fruehen-bildung/das-gute-kita-gesetz/mehr-qualitaet-undweniger-gebuehren/das-gute-kita-gesetz--fuer-gute-kitas-bundesweit/128214 (accessed 29 May 2020).

BMFSFJ (2017), Entry to ECEC: Building Bridges to Early Education - Flyer, BMFSFJ, Berlin, https://www.bmfsfj. de/blob/118648/a12abacdf6ebe0c55ca89f8571ca8236/bundesprogramm-kita-einstieg-bruecken-bauen-infruehe-bildung-data.pdf.

Brauckmann, S. et al. (2016), "Instructional Leadership in Germany: An Evolutionary Perspective", International Studies in Educational Administration, Vol. 44, pp. 5-20, https://www.researchgate.net/publication/309563088 Instructional Leadership in Germany An Evolution ary Perspective.

Brümmer, F. et al. (2018), Quality Initiative for Enhancing Teacher Training: Interim Evaluation, Ramboll Management Consulting, Hamburg, https://de.ramboll.com/-/media/files/rde/management-consulting/ studien handreichungen/qualitaetsoffensive lehrerbildung zwischenbericht der evaluation.pdf?la=de.

Busemeyer, M. and J. Vossiek (2015), "Reforming Education Governance Through Local Capacity-building: A Case Study of the "Learning Locally" Programme in Germany", OECD Education Working Papers, No. 113, OECD Publishing, Paris, https://doi.org/10.1787/5js6bhl2mxjg-en.

Cedefop (2019), "Germany: VET Law Modernisation”, News and Press, European Centre for the Development of Vocational Training (Cedefop), webpage, https://www.cedefop.europa.eu/en/news-and-press/news/ germany-vet-law-modernisation (accessed 11 June 2020).

Centre for Quality Assurance and Development \& Prognos AG (2016), Evaluation of the Quality Pact for Teaching, Centre for Quality Assurance and Development, Berlin, https://www.bmbf.de/files/Abschlussbericht Evaluation barrierefrei.pdf.

Deutscher Bundestag (2018), The Good Day Care Facilities Act, Federal Law Gazette 2018, Part I: No. 49, 31 December 2018, Bonn, https://www.bmfsfj.de/blob/133310/80763d0f167ce2687eb79118b8b1e721/gutekita-bgbl-data.pdf.

Deutscher Bundestag (2018), The Qualifications Opportunities Act, Federal Law Gazette 2018, Part I: No. 48, 21 December 2018, Bonn, https://www.bgbl.de/xaver/bgbl/start.xav?startbk=Bundesanzeiger BGBI\&jumpTo= bgbl118s2651.pdf\# bgbl \%2F\%2F*\%5B\%40attr id\%3D\%27bgbl118s2651.pdf\%27\%5D 1581951236 $\underline{358}$.

Deutscher Bundestag (2017), Law on the Further Quantitative and Qualitative Expansion of Childcare, Federal Law Gazette 2017, Part I: No. 40, 29 June 2017, Bonn, https://www.bgbl.de/xaver/bgbl/start.xav? startbk=Bundesanzeiger BGBI\&jumpTo=bgbl117s1893.pdf\# bgbl \%2F\%2F*\%5B\%40attr id \%3D $\% 27 \mathrm{~b}$ gbl117s1893.pdf\%27\%5D 1581957828343.

Deutscher Bundestag (2008), The Childcare Funding Act, Federal Law Gazette 2008, Part I: No. 57, 15 December 2008, Bonn, https://www.fruehe-chancen.de/fileadmin/PDF/Fruehe Chancen/Kifoeg/ kifoeg 20151201.pdf.

Deutscher Bundestag (1949), Basic Law for the Federal Republic of Germany, Bonn, https://www.btgbestellservice.de/pdf/80201000.pdf.

Easley, J. and P. Tulowitzki (eds.) (2016), Educational Accountability: International Perspectives on Challenges and Possibilities for School Leadership, Routledge, Oxon, https://www.routledge.com/EducationalAccountability-International-perspectives-on-challenges-and/Easley-II-Tulowitzki/p/book/ 9781138777897.

EC (2020), Commission Staff Working Document: Country Report Germany 2020, SWD(2020) 504 final, EC, Brussels, https://eur-lex.europa.eu/legal-content/EN/TXT/?qid=1584543810241\&uri= CELEX\%3A52020SC0504.

EC (2019), Education and Training Monitor 2019: Germany, Publications Office of the European Union, Luxembourg, https://ec.europa.eu/education/sites/education/files/document-library-docs/et-monitor-report2019-germany en.pdf.

EC (2019), Commission Staff Working Document: Country Report Germany 2019, SWD(2019) 202 final, Brussels, https://ec.europa.eu/info/sites/info/files/file import/2019-european-semester-country-reportgermany en.pdf. 


\section{8 | No. 16 - EDUCATION POLICY OUTLOOK IN GERMANY}

EC (2018), Education and Training Monitor 2018: Germany, Publications Office of the European Union, Luxembourg, https://ec.europa.eu/education/sites/education/files/document-library-docs/et-monitor-report2018-germany en.pdf.

EC (2018), Commission Staff Working Document: Country Report Germany 2018, SWD(2018) 202 final, Brussels, https://ec.europa.eu/info/sites/info/files/2018-european-semester-country-report-germany-en.pdf.

EC (2010), Europe 2020: A European Strategy for Smart, Sustainable and Inclusive Growth, EC, Brussels, https://eur-lex.europa.eu/legal-content/EN/TXT/PDF/?uri=CELEX:52010DC2020\&from=en.

EC/EACEA/Eurydice (2020), "Ongoing Reforms and Policy Developments", Eurydice - Germany, webpage, https://eacea.ec.europa.eu/national-policies/eurydice/content/ongoing-reforms-and-policy-developments25 en (accessed 11 June 2020).

European Agency for Special Needs and Inclusive Education (2020), "Country information for Germany - Teacher education for inclusive education”, Country Information - Germany, webpage, https://www.europeanagency.org/country-information/germany/teacher-education-for-inclusive-education (accessed 11 June 2020).

Fazekas, M. and S. Field (2013), A Skills Beyond School Review of Germany, OECD Reviews of Vocational Education and Training, OECD Publishing, Paris, https://doi.org/10.1787/9789264202146-en.

Federal Agency for Education Policy (2017), "Which secondary schools are there in Germany and which courses are taught there?", Society - Education - School, Federal Agency for Education Policy, webpage, https://www.bpb.de/gesellschaft/bildung/zukunft-bildung/256373/welche-sekundarschulen-gibt-es-indeutschland-und-welche-bildungsgaenge-werden-dort-unterrichtet (accessed 29 May 2020).

Federal Employment Agency (2017), My Skills: Identifying Professional Competencies, Federal Employment Agency, Nuremberg, https://www.arbeitsagentur.de/datei/dok ba014959.pdf.

Federal Government of Germany (2019), National Skills Strategy (in CVET): Strategy Paper, Berlin, https://www.bmbf.de/files/NWS Strategiepapier barrierefrei DE.pdf.

Federal Ministry of Justice and Consumer Protection (2016), German Language Promotion Ordinance of 4 May 2016, Federal Office of Justice, Bonn, https://www.bamf.de/SharedDocs/Anlagen/DE/Integration/ Berufsbezsprachf-ESF-BAMF/BSK-Rechtsgrundlagen/vo-berufsbezogene-deutschsprachfoerderung. pdf? blob=publicationFile\&v=7.

Huber, S., P. Tulowitzki and U. Hameyer (2017), "School Leadership and Curriculum: German Perspectives", Leadership and Policy in Schools, Vol. 16/2, pp. 272-302, https://www.tandfonline.com/doi/full/10.1080/15700763.2017.1298816.

IHK zu Coburg (2020), Unsere Wirtschaft [Our Economy], Magazine, https://www.coburg.ihk.de/media/uw 892016 internet.pdf (accessed 19 June 2020).

International Commission of Experts on the Excellence Initiative (2016), Final Evaluation - January 2016, Institute for Innovation and Technology, Berlin, https://www.gwk-bonn.de/fileadmin/Redaktion/Dokumente/Papers/ Imboden-Bericht-2016.pdf.

Joint Science Conference (2018), Federal-State Agreement: Programme for Female Professors - Phase III, 21 February 2018, Bonn, https://www.gwk-bonn.de/fileadmin/Redaktion/Dokumente/Papers/Professorinnen programm-III-2018.pdf.

Joint Science Conference (2016), Federal-State Agreement: Excellence Strategy, 19 October 2016, Bonn, https://www.bmbf.de/files/2016-10-27\%20Verwaltungsvereinbarung\%20Exzellenzstrategie\%20 veroeffentlicht.pdf.

Joint Science Conference (2013), Quality Initiative for Enhancing Teacher Training, Article 91b of the Basic Law, 12 April 2013, Bonn, https://www.gwk-bonn.de/fileadmin/Redaktion/Dokumente/Papers/Bund-LaenderVereinbarung-Qualitaetsoffensive-Lehrerbildung.pdf.

Klemm, K. and D. Zorn (2018), Teachers Urgently Wanted - Need and Offer for the Primary Level, Bertelsmann Foundation, Gütersloh, https://www.bertelsmann-stiftung.de/fileadmin/files/BSt/Publikationen/Graue Publikationen/BST-17-032 Broschuere-Lehrkraefte dringend gesucht GESAMT WEB.pdf.

Klinkhammer, N. et al. (eds.) (2017), Monitoring Quality in Early Childhood Education and Care - Approaches and experiences from selected countries, German Youth Institute, Munich, https://www.dji.de/fileadmin/user upload/bibs2017/Monitoring Sammelband E final.pdf. 
KMK (2020), Länd- specific Key Points for the Further Training of Teachers as Part of their Professionalisation in the Third Phase of Teacher Training, Decision of the KMK on 12 March 2020, KMK, Berlin, https://www.kmk.org/fileadmin/Dateien/veroeffentlichungen beschluesse/2020/2020 03 12-FortbildungLehrkraefte.pdf.

KMK (2019), Standards for Teacher Education: Educational science, Decision of the KMK on 16 December 2004 - updated version 16 May 2019, KMK, Berlin, https://www.kmk.org/fileadmin/veroeffentlichungen beschluesse/2004/2004 12 16-Standards-Lehrerbildung-Bildungswissenschaften.pdf.

KMK (2019), The Education System in the Federal Republic of Germany 2016/2017: A Description of the Responsibilities, Structures and Developments in Education Policy for the Exchange of Information in Europe (Excerpt), KMK, Berlin, https://www.kmk.org/fileadmin/Dateien/pdf/Eurydice/Bildungswesen-englpdfs/teachers.pdf.

KMK (2019), Federal-State Agreement: Digital School Pact 2019-24, 06 May 2019, KMK, Berlin, https://www.digitalpaktschule.de/files/VV DigitalPaktSchule Web.pdf.

KMK (2019), Joint Initiative by the Federal and State Governments to Support Disadvantaged Schools: School Makes you Strong, Decision of the KMK on 23 October 2019, KMK, Berlin, https://www.bmbf.de/files/ vereinbarung.pdf.

KMK (2019), Federal-State Agreement (BLV): Strengthening the Future Contract for Studying and Teaching, 06 June 2019, KMK, Berlin, https://www.bmbf.de/files/Verwaltungsvereinbarung-ZV Studium und Lehre staerken.pdf.

KMK (2017), Implementation Review - the Support Strategy for Low Performing Students, Decision of the KMK on 14 September 2017, KMK, Berlin, https://www.kmk.org/fileadmin/Dateien/veroeffentlichungen beschluesse/2017/2017 09 14-Umsetzung-Foerderstrategie.pdf.

KMK (2016), Joint Initiative by the Federal and State Governments to Promote High-performing Students, Decision of the KMK on 10 November 2016, KMK, Berlin, https://www.kmk.org/fileadmin/Dateien/ veroeffentlichungen beschluesse/2016/2016 11 10-Gemeinsame-Initiative-Foerderung-leistungsstarkeSchueler.pdf.

KMK (2016), The Standing Conference's "Education in the Digital World" Strategy - Summary, KMK, Berlin, https://www.kmk.org/fileadmin/Dateien/pdf/PresseUndAktuelles/2017/KMK-Strategie Bildung in der digitalen Welt Zusammenfassung en.pdf.

KMK (2015), Support Strategy for High-Achieving Students, Decision of the KMK on 11 June 2015, KMK, Berlin, https://www.kmk.org/fileadmin/Dateien/pdf/350-KMK-TOP-011-Fu-Leistungsstarke - neu.pdf.

KMK (2015), Overall Strategy from the Conference of Ministers of Education for Educational Monitoring, KMK, Berlin, https://www.kmk.org/fileadmin/Dateien/veroeffentlichungen beschluesse/2015/2015 06 11Gesamtstrategie-Bildungsmonitoring.pdf.

KMK (2010), The Support Strategy for Underperforming Pupils, Decision of the KMK on 4 March 2010, KMK, Berlin, https://www.kmk.org/fileadmin/veroeffentlichungen beschluesse/2010/2010 03 04Foerderstrategie-Leistungsschwaechere.pdf.

KMK (2007), Integration as an Opportunity - Together for More Equal Opportunities: Joint Declaration by the Conference of Ministers of Culture and Organisations for people with a Migrant Background, 13 December 2007, KMK, Berlin, https://www.kmk.org/fileadmin/Dateien/veroeffentlichungen beschluesse/2007/2007 12 13-Integration.pdf.

Kubicka, D., A. Wojciechowicz and M. Vock (2018), Refugee Teachers Programme: Interim Report, University of Potsdam, Potsdam, https://www.uni-potsdam.de/fileadmin01/projects/unterrichtsinterventionsforsch/ Zwischenbericht Kubicka Wojciechowicz Vock Stand 04.05.2018 1 .pdf.

Leibniz Institute for the Social Sciences (2017), Evaluation of the Programme for Female Professors, Skills Centre Women in Science and Research, Cologne, https://www.gwk-bonn.de/fileadmin/Redaktion/ Dokumente/Papers/Evaluation des Professorinnenprogramms-Bericht Januar 2017.pdf.

Maaz, K., S. Böse, and M. Neumann (2016), Scientific Support and Evaluation of the Bonus Programme to Support Schools in Difficult Situations in Berlin: Interim Report, The Liebniz Institute for Research and Information in Education, Berlin, https://www.dipf.de/de/forschung/aktuelle-projekte/pdf/steubis/bonusstudie-zwischenbericht. 


\section{0 | No. 16 - EDUCATION POLICY OUTLOOK IN GERMANY}

Moe, T. and S. Wiborg (eds.) (2017), The Comparative Politics of Education: Teachers Unions and Education Systems Around the World, Cambridge University Press, Cambridge, https://www.cambridge.org/fr/ academic/subjects/politics-international-relations/comparative-politics/comparative-politics-educationteachers-unions-and-education-systems-around-world?format=HB\&isbn=9781107168886.

OECD (2020), PISA 2018 Results (Volume III): What School Life Means for Students' Lives, PISA, OECD Publishing, Paris, https://doi.org/10.1787/acd78851-en.

OECD (2020), Foreign-born population (indicator), https://doi.org/10.1787/5a368e1b-en (accessed 20 April 2020).

OECD (2020), Inflows of foreign population (indicator), International Migration Database, https://stats.oecd.org/ (accessed 20 April 2020).

OECD (2020), Young population (indicator), https://doi.org/10.1787/3d774f19-en (accessed 14 April 2020).

OECD (2019), Good Practice for Good Jobs in Early Childhood Education and Care, OECD Publishing, Paris, https://doi.org/10.1787/64562be6-en.

OECD (2019), Good Practice for Good Jobs in Early Childhood Education and Care: Eight Policy Measures from OECD Countries, OECD Publishing, Paris, http://www.oecd.org/els/family/Good-Practice-Good-JobsECEC-Booklet EN.pdf.

OECD (2019), Programme for International Student Assessment (PISA) Results from PISA 2018: Country Note of Germany, OECD Publishing, Paris, http://www.oecd.org/pisa/publications/PISA2018 CN DEU.pdf.

OECD (2019), Education Policy Outlook 2019: Working Together to Help Students Achieve their Potential, OECD Publishing, Paris, https://doi.org/10.1787/2b8ad56e-en.

OECD (2019), Education at a Glance 2019: OECD Indicators, OECD Publishing, Paris, https://doi.org/10.1787/f8d7880d-en.

OECD (2019), PISA 2018 Results (Volume II): Where All Students Can Succeed, PISA, OECD Publishing, Paris, https://doi.org/10.1787/b5fd1b8f-en.

OECD (2019), PISA 2018 Results (Volume I): What Students Know and Can Do, PISA, OECD Publishing, Paris, https://doi.org/10.1787/5f07c754-en.

OECD (2019), Providing Quality Early Childhood Education and Care: Results from the Starting Strong Survey 2018, TALIS, OECD Publishing, Paris, https://doi.org/10.1787/301005d1-en.

OECD (2018), Education at a Glance 2018: OECD Indicators, OECD Publishing, Paris, https://doi.org/10.1787/eag-2018-en.

OECD (2018), Education Policy Outlook 2018: Putting Student Learning at the Centre, OECD Publishing, Paris, https://doi.org/10.1787/9789264301528-en.

OECD (2018), Effective Teacher Policies: Insights from PISA, PISA, OECD Publishing. http://dx.doi.org/10.1787/9789264301603-en.

OECD (2018), Equity in Education: Breaking Down Barriers to Social Mobility, PISA, OECD Publishing, Paris, https://doi.org/10.1787/9789264073234-en.

OECD (2018), OECD Economic Surveys: Germany 2018, OECD Publishing, Paris, https://doi.org/10.1787/eco surveys-deu-2018-en.

OECD (2017), Finding Their Way: Labour Market Integration of Refugees in Germany, OECD Publishing, Paris, https://www.oecd.org/els/mig/Finding-their-Way-Germany.pdf.

OECD (2017), Skills Outlook 2017: Skills and Global Value Chains - Country Note, Germany, OECD Publishing, Paris, https://www.oecd.org/skills/OECD-Skills-Outlook-2017-Skills-and-Global-Value-Chains-CountryNote-Germany.pdf.

OECD (2017), Starting Strong 2017: Key OECD Indicators on Early Childhood Education and Care, Starting Strong, OECD Publishing, Paris, https://doi.org/10.1787/9789264276116-en.

OECD (2017), The Funding of School Education: Connecting Resources and Learning, OECD Reviews of School Resources, OECD Publishing, Paris, https://doi.org/10.1787/9789264276147-en.

OECD (2016), OECD Economic Surveys: Germany 2016, OECD Publishing, Paris, https://doi.org/10.1787/eco surveys-deu-2016-en. 


\section{1 | No. 16 - EDUCATION POLICY OUTLOOK IN GERMANY}

OECD (2016), PISA 2015 Results (Volume II): PISA 2015 Results (Volume II): Policies and Practices for Successful Schools, PISA, OECD Publishing, Paris, https://www.oecd-ilibrary.org/education/pisa-2015results-volume-ii 9789264267510-en.

OECD (2016), Starting Strong IV: Early Childhood Education and Care Data Country Note: Germany, http://www.oecd.org/education/school/ECECDCN-Germany.pdf.

OECD (2016), Starting Strong IV: Monitoring Quality in Early Childhood Education and Care, Starting Strong, Country Note: Germany, OECD Publishing, Paris, http://www.oecd.org/education/school/ECECMNGermany.pdf.

OECD (2010), OECD Economic Surveys: Germany 2010, OECD Publishing, Paris, https://doi.org/10.1787/eco surveys-deu-2010-en.

OECD/EU (2018), Settling In 2018: Indicators of Immigrant Integration, OECD Publishing, Paris/EU, Brussels, https://doi.org/10.1787/9789264307216-en.

Senate Department for Education, Youth and Family of Berlin (2019), "Bonus Program”, Support - Bonus Programme, Berlin, https://www.berlin.de/sen/bildung/unterstuetzung/bonus-programm/.

Stein, A. and K. Bock-Famulla (2018), Expanding Daycare: Gaps Between the Länder Remain, Bertelsmann Stiftung, Gütersloh, https://www.bertelsmann-stiftung.de/de/themen/aktuelle-meldungen/2018/august/kitaausbau-kluft-zwischen-laendern-bleibt/.

Sugarman, J., S. Morris-Lange and M. McHugh (2016), Improving Education for Migrant-Background Students: A Translatlantic Comparison of School Funding, Migration Policy Institute, Washington D.C., https://www.migrationpolicy.org/sites/default/files/publications/TransatlanticFunding FINAL.pdf.

Tangermann, J. and J. Grote (2018), Labour Market Integration of Third-Country Nationals in Germany: Study by the German National Contact Point for the European Migration Network (EMN), Working Paper 82, Federal Office for Migration and Refugees, Nuremberg, https://ec.europa.eu/homeaffairs/sites/homeaffairs/ files/11a germany labour market integration final en.pdf.

Vock, M. (2017), Refugee Teachers Programme, University of Potsdam, SchVw NRW: 10/2017, https://www.unipotsdam.de/fileadmin01/projects/unterrichtsinterventionsforsch/SchVw NRW 201710 Vock.pdf.

Winterhager, N. et al. (2017), Impact Evaluation of the Higher Education pact 2020: Final Report/Summary, Institute of Innovation and Technology, Berlin, https://www.bmbf.de/files/08.12.2017\%20Kurzfassung\%20 Untersuchung\%20HSP\%20iit BARRIEREFREI.PDF. 


\section{NOTES}

1 On 25 May 2018, the OECD Council invited Colombia to become a Member. While Colombia is included in the OECD averages reported in this publication for data from Education at a Glance, the Programme for International Student Assessment and the Teaching and Learning International Survey, at the time of preparation of these OECD datasets, Colombia was in the process of completing its domestic procedures for ratification and the deposit of Colombia's instrument of accession to the OECD Convention was pending.

2 There is a break in the time series, as data for 2018 refer to ISCED 2011 while data for 2008 refer to ISCED-97.

3 In PISA, the phrase, "Students with an immigrant background" refers to those students whose mother and father were born in a country/economy other than that where the student sat the PISA test. This includes both firstgeneration (foreign-born students whose parents are both foreign-born) and second-generation (students born in the country of assessment but whose parents are both foreign-born) immigrant students. The National German PISA report though, also counts students with one parental part being born abroad as "immigrant students" and come to a share of around $35.6 \%$ for PISA 2018. According to this estimation, there was an increase of 10 percentage points since PISA 2009 in the share of immigrant students in Germany.

${ }^{4}$ With the exception of Berlin and Brandenburg (grade 7).

${ }^{5}$ In Germany, the parental origin is based on the country of birth of parents for the native-born still living with their parents, but is based on own citizenship or the citizenship at birth of the parents for those who do not live anymore with their parents. Therefore, the so-called native-born with foreign-born parents may also include native-born with one foreign- and one native-born parent (the latter being an offspring of foreign-born parents), as well as nativeborn with two native-born parents who are both themselves offspring of foreign-born parents.

${ }^{6}$ For Germany, the proportion of the population covered by the sample was between $50 \%$ and $75 \%$ for index of sense of belonging.

${ }^{7}$ For Germany, this refers to the typical teaching time (teaching time required from most teachers when no specific circumstances apply to teachers).

This paper is published under the responsibility of the Secretary-General of the OECD. The opinions expressed and arguments employed herein do not necessarily reflect the official views of OECD member countries or the European Union.

This document and any map included herein are without prejudice to the status of or sovereignty over any territory, to the delimitation of international frontiers and boundaries and to the name of any territory, city or area.

Photo credits: Cover (C) Shutterstock/Sasha Chebotarev

(C) OECD 2020

The use of this work, whether digital or print, is governed by the Terms and Conditions to be found at http://www.oecd.org/termsandconditions 
This document has also been published as:

OECD (2020), Education Policy Outlook: Germany, available at: www.oecd.org/education/policy-outlook/country-profile-Germany-2020.pdf.

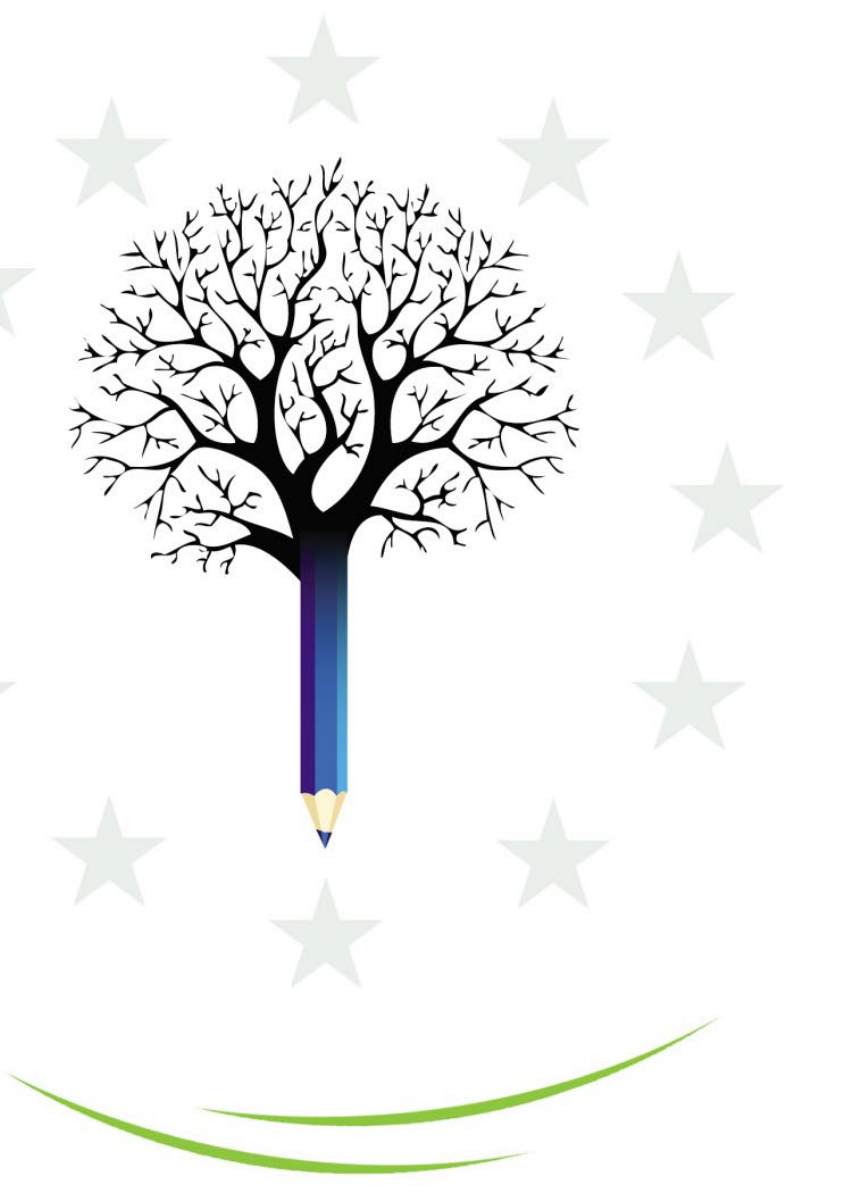

www.oecd.org/edu/policyoutlook.htm

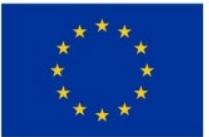

